\title{
Contraceptive Method Skew and Shifts in Method Mix In Low- and Middle-Income Countries
}

By Jane T. Bertrand, Tara M. Sullivan, Ellen A. Knowles, Muhammad F. Zeeshan and James D. Shelton

Jane Bertrand is professor and chair, and at the

time this research was conducted,

Ellen A. Knowles was research assistant-both with the Department of Global Health Systems and Development, Tulane University School of Public Health and Tropical Medicine, New Orleans, LA,

USA. Tara M. Sullivan is project director, Knowledge for Health

Project, Center for Communication Programs, Johns Hopkins

Bloomberg School of

Public Health, Baltimore, MD, USA. At

the time this research was conducted, Muhammad F.

Zeeshan was doctoral student, The Ohio State University College of Public Health, Columbus, OH, USA.

James D. Shelton is an independent consultant.

\begin{abstract}
CONTEXT: Method mix - the percentage distribution of contraceptive users in a given country, by method-is one measure that reflects the availability of a range of contraceptive methods. A skewed method mix-one in which $50 \%$ or more of contraceptive users rely on a single method - could be cause for concern as a sign of insufficiency of alternative methods or provider bias. Shifts in method mix are important to individual countries, donors and scholars studying contraceptive dynamics.
\end{abstract}

METHODS: To determine current patterns and recent changes in method mix, we examined 109 low- and middleincome countries. A variety of statistical methods were used to test four factors as correlates of skewed method mix: geographic region, family planning program effort index, modern contraceptive prevalence rate and human development index. An assessment of changes in reliance on female and male sterilization, the IUD, the implant and the injectable was conducted for countries with available data.

RESULTS: Of the 109 countries included in this analysis, 30\% had a skewed method mix-a modest decrease from $35 \%$ in a 2006 analysis. Only geographic region showed any correlation with method skew, but it was only marginally significant. The proportion of users relying on female sterilization, male sterilization or the IUD decreased in far more countries than it increased; the pattern was reversed for the injectable.

CONCLUSION: Method mix skew is not a definitive indicator of lack of contraceptive choice or provider bias; it may instead reflect cultural preferences. In countries with a skewed method mix, investigation is warranted to identify the cause.

International Perspectives on Sexual and Reproductive Health, 2014, 40(3):144-153, doi: 10.1363/4014414

Over the 20-year period following the 1994 International Conference on Population and Development (ICPD) in Cairo, family planning has waned as a priority on the global health agenda, ${ }^{1,2}$ although some signs of renewed interest and investment have occurred in recent years. In 2005, "universal access to reproductive health" was added to Millennium Goal 5, albeit as an afterthought. In addition, three international family planning conferences have taken place, in 2009 (Uganda), 2011 (Senegal) and 2013 (Ethiopia). The high-profile Family Planning Summit 2020-held in London in July 2012 and sponsored by the Bill and Melinda Gates Foundation, the United Kingdom Department for International Development and the United Nations (UN) Population Fund, among othersconcluded in 11 donor countries and 22 developing countries pledging funding, commodities and political support to reach the ambitious goal of making affordable lifesaving contraceptive information, services and supplies available to an additional 120 million women in the world's poorest countries by $2020 .^{3}$

Family planning advocates have applauded this initiative to increase access to family planning services for women and men throughout the developing world. However, human rights and women's groups, among others, have expressed concern that in the rush to meet the 2020 goal, issues of voluntary use, reproductive choice, quality of care and client-centered service delivery may be compromised. ${ }^{4}$

Although studies specifically focused on voluntary use and reproductive choice, ${ }^{5}$ quality of care in family planning services ${ }^{6-8}$ and discontinuation rates exist, ${ }^{9}$ there is no standard indicator from readily available data sources to measure these concepts. One relevant framework that is well-recognized and widely cited in family planning circles is the Bruce-Jain framework for quality of care. ${ }^{10}$ One of the framework's six elements is "choice of methods," which refers to the number of contraceptive methods available to clients on a consistent basis. Various questions have been used to capture this concept in surveys, such as "Did you receive the method you wished on the day of service?"; however, no standard question is used across existing data sources.

One proxy measure that reflects the availability of a range of contraceptive methods is method mix-that is, the percentage distribution of a country's contraceptive users (often married women of reproductive age) by method. This indicator is readily available from the Demographic and Health Survey (DHS), the Multiple Indicator Cluster Survey (MICS) and other nationally representative surveys that collect data on contraceptive use. In addition, programs offering contraceptives may calculate method mix 
for their own clientele from program data.

There is no right or ideal method mix, nor is there a gold standard for a balanced method mix. For a given country, however, the distribution of contraceptive use across methods provides de facto evidence that women or couples there have some degree of choice. By contrast, there may be cause for concern when the majority of users in a given country rely on a single method. Although such a situation could result from cultural beliefs or societal trends, it may also point to insufficiency of alternative methods or to provider bias. ${ }^{11}$ Moreover, it is hard to argue that a single method can meet the needs of widely differing subgroups (e.g., spacers, limiters, adolescents).

In the wake of ICPD, the guidance to give clients what they want, barring medical contraindications, may have inadvertently reinforced the effect of social norms. Rather than hearing an in-depth presentation of the range of contraceptive options, a client may instead opt for the method recommended by her friends or family members, thus reinforcing the preference for a given method. This scenario results in a positive outcome-the client receiving her method of choice-and helps explain why certain methods continue to dominate the method mix in a given country.

Over the past decade, contraceptive methods have improved and new contraceptive methods have been brought to market, together offering women a wider variety of acceptable choices. For example, the first implant, Norplant, came to market 30 years ago, but has since been supplanted by new devices that are easier to insert and remove. ${ }^{12,13}$ Use of the injectable has increased dramatically in many countries worldwide since its approval in 1992 by the United States Food and Drug Administration. ${ }^{14}$ The popularity of the method can be traced to a number of factors: length of effectiveness (up to three months for some brands), discretion (can be used without partner's or family's knowledge), no requirement of a pelvic exam and ease of insertion.

In addition to improving and enhancing method choice, efforts have been undertaken to reduce costs and increase access by expanding market segmentation and by using a total market approach-allowing clients to choose a particular method based on price and brand through the public or private sector, including social marketing. ${ }^{13}$

Sullivan et al. explored the issue of method skew in 96 countries between 1984 and 2004. ${ }^{11}$ In this article, we update and expand on that previous analysis, prompted by the surge of interest in voluntary use and choice in the wake of the London Family Planning Summit; ${ }^{4}$ the shifts in contraceptive trends, including method preferences, reported at the global and regional level; ${ }^{15}$ and the introduction of new methods. We aim to assess current patterns and recent changes in method mix skew in low- and middle-income countries since Sullivan et al.'s article; to test four factors as correlates of skew; to assess changes in the reliance of countries on specific methods; and to explore the underlying factors that explain skew and shifts observed toward or away from specific methods.

\section{METHODS}

We limited our analysis to the 109 countries that had been classified as a low- or middle-income country by the World Bank as of 2012, ${ }^{* 16}$ had available data from a nationally representative survey on contraceptive use after 2005 and had a population of at least one million people as of 2011. ${ }^{17}$ Data were drawn from the 2012 UN World Contraceptive Use report, which provides data on the breakdown of method mix, based on its compilation of DHS, MICS and other nationally representative surveys with relevant data. ${ }^{18}$ We updated this information with individual DHS reports, DHS preliminary reports, MICS-4 data and other national surveys that became available after the publication of the report. The analysis examined data from the latest available surveys.

Modern contraceptive methods included female and male sterilization, the pill, the injectable, the IUD, the implant, male condoms and other barrier methods (i.e., female condoms, jelly/spermicide and the sponge). The implant-not listed as a separate category in Sullivan et al.'s article $^{11}$-was included in this analysis, now that implant data from 51 countries are available. Traditional methods included withdrawal and periodic abstinence (i.e., the rhythm method). The lactational amenorrhea method was excluded by Sullivan and from this analysis; data show that respondents are not able to reliably report on use of this method. ${ }^{19}$ In addition, the Standard Days Method was not included, despite being used in a growing number of countries since its introduction in 2002; ${ }^{20}$ the method is not always listed as a separate category in the DHS or related surveys.

We considered a country's method mix to be skewed if $50 \%$ or more of the married women of reproductive age in that country who practiced contraception used one contraceptive method. ${ }^{11}$ For countries for which both pre- and post-2005 data were available, we compared method mix skew in the two periods. We describe a country's method mix as "still skewed" if it was skewed in the country's most recent survey prior to 2005 and its most recent survey since 2005; "recently skewed" if it was skewed in the country's most recent survey since 2005, but not in its most recent survey prior to 2005; and "no longer skewed" if it was skewed in the country's most recent survey prior to 2005, but not in its most recent survey since 2005.

We tested four variables as correlates of method skew. For geographic region, we conducted a Fisher's exact test; for family planning program effort index, we used a twosample t test to compare the means on the total score and on the score for "access to methods" for two groups of countries (with and without skew); for modern contraceptive prevalence, we used separate simple logistic regressions (with method skew treated as a binary dependent variable, and modern contraceptive prevalence treated as a continuous variable); and for the human development

*The classification of countries by region in this analysis conforms to that presented by the World Bank. 
TABLE 1. Method mix and contraceptive prevalence rate for married women of reproductive age, by region and country

\begin{tabular}{|c|c|c|c|c|c|c|c|c|c|c|c|}
\hline \multirow[t]{2}{*}{ Region/country } & \multirow{2}{*}{$\begin{array}{l}\text { Latest available } \\
\text { survey }\end{array}$} & \multicolumn{2}{|c|}{ Sterilization } & \multirow[t]{2}{*}{ Pill } & \multirow[t]{2}{*}{ Injectable } & \multirow[t]{2}{*}{ IUD } & \multirow[t]{2}{*}{ Condom } & Implant & Other & Traditional & CPR \\
\hline & & Female & Male & & & & & & & & \\
\hline Sub-Saharan Africa & & & & & & & & & & & \\
\hline Angola & MICS, 2001 & 1.7 & 0.0 & 37.3 & 23.7 & 6.8 & 5.1 & 0.0 & 3.4 & 22.0 & 6.2 \\
\hline Benin & MICS, 2011-2012 & 1.0 & 0.0 & 13.0 & 20.0 & 5.0 & 18.0 & 0.0 & 6.0 & 37.0 & 12.9 \\
\hline Botswana* & NS, 2007-2008 & 3.5 & 0.2 & 10.1 & 11.2 & 1.3 & 68.8 & 0.0 & 1.0 & 4.0 & 52.8 \\
\hline Burkina Faso & DHS, 2010 & 1.3 & 0.0 & 20.0 & 28.8 & 1.9 & 10.0 & 21.3 & 0.6 & 6.3 & 16.2 \\
\hline Burundit & DHS, 2010 & 2.7 & 0.0 & 11.0 & 47.5 & 12.3 & 0.0 & 2.7 & 4.6 & 19.2 & 21.9 \\
\hline Cameroon & DHS, 2011 & 2.2 & 0.0 & 8.4 & 13.3 & 0.9 & 33.8 & 3.1 & 0.4 & 37.8 & 23.4 \\
\hline Central African Rep.† & MICS, 2010 & 1.6 & 0.0 & 48.4 & 4.1 & 0.0 & 18.9 & 1.6 & 0.8 & 24.6 & 15.2 \\
\hline Chadt & MICS, 2010 & 5.3 & 0.0 & 26.3 & 47.4 & 0.0 & 5.3 & 0.0 & 0.0 & 15.8 & 4.8 \\
\hline Congo-Brazzaville* & DHS-P, 2011-2012 & 0.2 & 0.0 & 6.8 & 6.6 & 0.0 & 28.8 & 0.2 & 4.0 & 53.4 & 44.7 \\
\hline Côte d'Ivoire & DHS-P,2011 & 0.6 & 0.0 & 43.0 & 14.5 & 0.6 & 10.9 & 1.2 & 1.8 & 27.3 & 18.2 \\
\hline Dem.Rep.of Congo* & MICS, 2010 & 5.3 & 0.0 & 6.7 & 4.7 & 0.7 & 16.7 & 2.0 & 0.7 & 63.3 & 17.7 \\
\hline Eritrea & DHS,2002 & 3.3 & 0.0 & 23.3 & 43.3 & 6.7 & 10.0 & 0.0 & 0.0 & 13.3 & 8.0 \\
\hline Ethiopia* & DHS, 2011 & 1.8 & 0.0 & 7.4 & 73.0 & 1.1 & 0.7 & 11.9 & 0.0 & 4.2 & 28.6 \\
\hline Gabon & DHS-P,2012 & 1.9 & 0.0 & 18.5 & 1.3 & 0.3 & 39.0 & 0.0 & 1.9 & 37.0 & 31.1 \\
\hline Gambia,The & NS, 2001 & 4.7 & 0.0 & 43.3 & 23.3 & 9.3 & 3.3 & 0.0 & 0.7 & 15.3 & 17.5 \\
\hline Ghana & DHS, 2008 & 7.1 & 0.0 & 20.9 & 27.6 & 0.9 & 10.7 & 4.0 & 1.8 & 27.1 & 23.5 \\
\hline Guinea & DHS-P,2012 & 2.5 & 0.0 & 30.0 & 32.5 & 5.0 & 12.5 & 2.5 & 0.0 & 15.0 & 5.6 \\
\hline Guinea-Bissau & MICS, 2010 & 0.0 & 0.0 & 11.0 & 13.8 & 36.7 & 29.4 & 0.0 & 0.0 & 9.2 & 14.2 \\
\hline Kenya† & DHS, 2008-2009 & 10.8 & 0.0 & 16.3 & 48.8 & 3.6 & 4.1 & 4.3 & 0.0 & 12.2 & 45.5 \\
\hline Lesotho & DHS, 2009 & 5.2 & 0.0 & 26.9 & 41.5 & 4.1 & 20.2 & 0.2 & 0.2 & 1.7 & 47.0 \\
\hline Liberia & DHS, 2007 & 5.2 & 0.0 & 33.0 & 35.7 & 1.7 & 13.9 & 0.0 & 0.0 & 10.4 & 11.4 \\
\hline Madagascart & DHS, 2008-2009 & 2.8 & 0.3 & 15.5 & 46.4 & 1.0 & 2.8 & 3.9 & 0.0 & 27.2 & 39.9 \\
\hline Malawi* & DHS, 2010 & 21.7 & 0.2 & 5.6 & 57.6 & 0.7 & 5.4 & 2.9 & 0.2 & 5.8 & 46.1 \\
\hline Mali & DHS, 2006 & 4.2 & 0.0 & 40.8 & 35.2 & 1.4 & 5.6 & 1.4 & 0.0 & 11.3 & 8.2 \\
\hline Mauritania* & MICS, 2007 & 1.1 & 0.0 & 62.0 & 10.9 & 3.3 & 4.3 & 0.0 & 5.4 & 13.0 & 9.3 \\
\hline Mauritius† & NS, 2002 & 11.7 & 0.1 & 21.1 & 4.9 & 1.8 & 11.7 & 0.1 & 0.3 & 48.2 & 75.8 \\
\hline Mozambique† & DHS-P,2011 & 1.8 & 0.0 & 39.8 & 45.1 & 0.9 & 9.7 & 0.0 & 0.9 & 1.8 & 11.4 \\
\hline Namibia & DHS, 2006-2007 & 19.0 & 0.7 & 15.9 & 40.2 & 2.6 & 19.6 & 0.4 & 0.4 & 1.3 & 55.1 \\
\hline Niger* & DHS-P,2012 & 1.2 & 0.0 & 67.5 & 25.3 & 1.2 & 0.0 & 3.6 & 0.0 & 1.2 & 13.9 \\
\hline Nigeria & DHS-P,2012 & 1.6 & 0.0 & 16.9 & 28.2 & 5.6 & 14.5 & 1.6 & 0.8 & 30.6 & 14.1 \\
\hline Rwanda* & DHS, 2010 & 1.6 & 0.0 & 13.9 & 51.6 & 1.0 & 5.7 & 12.4 & 0.2 & 13.7 & 51.6 \\
\hline Senegal & DHS, 2011 & 1.6 & 0.0 & 33.3 & 42.3 & 4.9 & 4.9 & 8.9 & 0.0 & 4.1 & 13.1 \\
\hline Sierra Leone† & MICS, 2010 & 0.0 & 0.0 & 43.0 & 49.5 & 0.0 & 1.1 & 6.5 & 0.0 & 0.0 & 11.0 \\
\hline Somalia & MICS, 2005-2006 & 0.0 & 0.0 & 44.4 & 11.1 & 5.6 & 0.0 & 0.0 & 0.0 & 38.9 & 14.6 \\
\hline South Africa† & DHS, 2003 & 23.9 & 1.2 & 18.2 & 47.4 & 1.7 & 7.7 & 0.0 & 0.0 & 0.0 & 59.9 \\
\hline South Sudan ${ }^{*} \neq$ & NS, 2006 & 0.0 & 0.0 & 14.6 & 0.0 & 0.0 & 73.5 & 0.0 & 6.8 & 5.1 & 3.5 \\
\hline Sudan* ${ }^{*} \neq$ & NS,2006 & 5.9 & 0.0 & 75.6 & 8.0 & 5.3 & 0.2 & 0.0 & 0.0 & 4.9 & 9.5 \\
\hline Swaziland & MICS, 2010 & 8.1 & 0.5 & 16.6 & 33.1 & 1.7 & 34.8 & 2.8 & 0.3 & 2.0 & 65.2 \\
\hline Tanzania & DHS, 2010 & 10.9 & 0.0 & 20.9 & 33.1 & 1.9 & 7.2 & 7.2 & 0.0 & 18.8 & 34.4 \\
\hline Togo & MICS, 2006 & 1.9 & 0.0 & 12.3 & 20.4 & 2.5 & 23.4 & 6.2 & 1.2 & 32.1 & 16.8 \\
\hline Uganda† & DHS, 2011 & 9.9 & 0.3 & 9.9 & 48.0 & 1.7 & 9.2 & 9.2 & 0.0 & 11.9 & 30.0 \\
\hline Zambia & DHS, 2007 & 5.7 & 0.0 & 32.8 & 25.4 & 0.3 & 14.0 & 1.2 & 0.3 & 20.3 & 40.8 \\
\hline Zimbabwe* & DHS, 2010-2011 & 1.9 & 0.0 & 71.1 & 14.3 & 0.3 & 5.3 & 4.6 & 0.5 & 1.9 & 58.5 \\
\hline Middle East/North A & & & & & & & & & & & \\
\hline Algeria* & MICS, 2006 & 1.9 & 0.0 & 77.4 & 0.0 & 3.9 & 3.9 & 0.0 & 0.5 & 12.5 & 61.4 \\
\hline Egypt* & DHS, 2008 & 1.7 & 0.0 & 20.4 & 12.7 & 62.0 & 1.2 & 0.9 & 0.0 & 1.0 & 60.3 \\
\hline Iran & NS, 2002 & 21.1 & 3.2 & 34.9 & 3.2 & 10.6 & 8.3 & 0.6 & 0.0 & 18.2 & 73.3 \\
\hline Iraq & MICS, 2011 & 5.7 & 0.0 & 31.3 & 6.5 & 19.4 & 3.7 & 0.2 & 1.2 & 31.9 & 51.2 \\
\hline Jordan & DHS-P,2012 & 3.7 & 0.0 & 13.8 & 1.5 & 36.3 & 13.5 & 0.5 & 0.3 & 30.3 & 61.2 \\
\hline Lebanon & PAPFAM,2006 & 9.1 & 0.0 & 37.5 & 0.0 & 40.7 & 12.7 & 0.0 & 0.0 & 0.0 & 58.0 \\
\hline Morocco* & DHS, 2003-2004 & 4.5 & 0.0 & 66.7 & 3.5 & 9.0 & 2.5 & 0.0 & 0.2 & 13.6 & 63.0 \\
\hline Syriat & MICS, 2006 & 2.2 & 0.0 & 24.2 & 1.7 & 48.1 & 3.0 & 0.0 & 0.4 & 20.4 & 58.3 \\
\hline Tunisiat & MICS, 2006 & 9.3 & 0.0 & 24.1 & 2.3 & 46.3 & 2.2 & 0.5 & 1.0 & 14.3 & 60.2 \\
\hline Yemen & MICS, 2006 & 11.1 & 0.0 & 43.3 & 16.8 & 19.2 & 1.9 & 0.0 & 0.0 & 7.7 & 27.7 \\
\hline Latin America/Caribl & & & & & & & & & & & \\
\hline Argentina & NS, 2004-2005 & 7.4 & 0.0 & 25.8 & 3.0 & 10.7 & 41.7 & 0.0 & 1.0 & 10.3 & 78.9 \\
\hline Bolivia & DHS, 2008 & 10.9 & 0.2 & 5.6 & 19.0 & 14.1 & 6.7 & 0.0 & 0.2 & 43.3 & 60.5 \\
\hline Brazil & NS, 2006 & 36.2 & 6.4 & 30.8 & 5.0 & 2.4 & 15.2 & 0.1 & 0.0 & 4.0 & 80.3 \\
\hline Chilet & NS, 2006 & 11.1 & 0.0 & 45.3 & 0.0 & 29.4 & 14.2 & 0.0 & 0.0 & 0.0 & 64.2 \\
\hline Colombia & DHS, 2010 & 44.4 & 4.3 & 9.7 & 11.7 & 9.5 & 8.9 & 3.9 & 0.1 & 7.4 & 79.1 \\
\hline Costa Rica & NS, 2010 & 36.1 & 7.1 & 25.6 & 11.4 & 4.1 & 10.8 & 0.4 & 0.6 & 3.9 & 82.2 \\
\hline Cuba & MICS, 2010-2011 & 32.3 & 0.1 & 7.0 & 1.9 & 33.6 & 23.2 & 0.1 & 0.5 & 1.1 & 74.3 \\
\hline Dom.Rep.* & DHS, 2007 & 65.5 & 0.0 & 18.5 & 5.8 & 2.9 & 2.6 & 0.8 & 0.0 & 3.9 & 72.9 \\
\hline Ecuador & RHS, 2004 & 33.7 & 0.0 & 18.5 & 8.2 & 14.0 & 6.0 & 0.0 & 1.3 & 18.4 & 72.7 \\
\hline El Salvador & RHS, 2008 & 44.5 & 0.4 & 7.6 & 31.2 & 1.1 & 6.4 & 0.1 & 0.0 & 8.7 & 72.5 \\
\hline Guatemala & RHS, 2008-2009 & 35.0 & 1.5 & 6.7 & 27.2 & 2.4 & 6.7 & 0.0 & 2.0 & 18.5 & 54.1 \\
\hline Haiti* & DHS-P,2012 & 5.2 & 0.3 & 9.8 & 67.8 & 0.3 & 0.0 & 6.6 & 0.3 & 9.4 & 34.5 \\
\hline Honduras & DHS, 2005-2006 & 32.6 & 0.5 & 17.4 & 21.2 & 10.2 & 4.5 & 0.0 & 0.0 & 13.7 & 65.2 \\
\hline Jamaica & RHS, 2008-2009 & 13.8 & 0.0 & 23.9 & 19.0 & 1.4 & 34.9 & 1.0 & 0.4 & 5.7 & 72.5 \\
\hline Mexico* & NS, 2006 & $58.3 \S$ & 0.0 & 7.1 & 7.5 & 17.4 & 9.6 & 0.0 & 0.0 & 0.0 & 70.9 \\
\hline
\end{tabular}


TABLE 1. continued

\begin{tabular}{|c|c|c|c|c|c|c|c|c|c|c|c|}
\hline \multirow[t]{2}{*}{ Region/country } & \multirow{2}{*}{$\begin{array}{l}\text { Latest available } \\
\text { survey }\end{array}$} & \multicolumn{2}{|c|}{ Sterilization } & \multirow[t]{2}{*}{ Pill } & \multirow[t]{2}{*}{ Injectable } & \multirow[t]{2}{*}{ IUD } & \multirow[t]{2}{*}{ Condom } & \multirow[t]{2}{*}{ Implant } & \multirow{2}{*}{$\begin{array}{l}\text { Other } \\
\text { modern }\end{array}$} & \multirow[t]{2}{*}{ Traditional } & \multirow[t]{2}{*}{ CPR } \\
\hline & & Female & Male & & & & & & & & \\
\hline \multicolumn{12}{|c|}{ Latin America/Caribbean continued } \\
\hline Panama & NS, 2009 & 34.6 & 0.0 & 22.3 & 27.0 & 9.7 & 6.4 & 0.0 & 0.0 & 0.0 & 52.2 \\
\hline Paraguay & RHS, 2008 & 12.5 & 0.3 & 22.8 & 20.9 & 15.6 & 16.7 & 0.0 & 0.1 & 11.1 & 79.4 \\
\hline Peru & DHS, 2011 & 12.7 & 0.5 & 11.2 & 24.2 & 3.5 & 16.2 & 0.1 & 0.4 & 31.2 & 75.4 \\
\hline Uruguay & $\mathrm{NS}, 2004$ & 7.0 & 1.0 & 31.0 & 0.0 & 16.0 & 40.0 & 0.0 & 2.1 & 2.9 & 77.0 \\
\hline \multicolumn{12}{|l|}{ Asia Pacific } \\
\hline Afghanistan & DHS-M, 2011 & 8.3 & 0.0 & 29.1 & 35.0 & 6.8 & 9.7 & 0.0 & 0.0 & 11.2 & 21.8 \\
\hline Bangladesh & DHS, 2011 & 8.2 & 2.0 & 44.8 & 18.5 & 1.2 & 9.1 & 1.8 & 0.0 & 14.5 & 61.2 \\
\hline Cambodia & $\mathrm{DHS}, 2010$ & 4.8 & 0.0 & 31.3 & 20.6 & 6.2 & 5.4 & 0.8 & 0.0 & 31.0 & 50.5 \\
\hline Chinat & NS, 2006 & 33.9 & 5.3 & 1.4 & 0.0 & 48.0 & 10.0 & 0.4 & 0.2 & 0.7 & 84.6 \\
\hline India* & NS, 2007-2008 & 65.7 & 2.0 & 6.6 & 0.0 & 3.3 & 10.1 & 0.0 & 0.6 & 11.7 & 54.8 \\
\hline Indonesia* & DHS-P, 2012 & 5.2 & 0.3 & 22.1 & 51.9 & 6.3 & 2.9 & 5.4 & 0.0 & 5.9 & 61.9 \\
\hline Laos & NS, 2005 & 12.4 & 0.0 & 42.1 & 28.0 & 7.7 & 2.1 & 0.0 & 0.0 & 7.7 & 38.4 \\
\hline Pakistan & LSMS, 2007-2008 & 24.3 & 0.0 & 7.1 & 10.1 & 9.4 & 20.2 & 0.0 & 1.1 & 27.7 & 27.0 \\
\hline Philippines* & NS, 2011 & 23.7 & 0.3 & 54.5 & 9.4 & 8.5 & 3.3 & 0.0 & 0.0 & 0.3 & 48.9 \\
\hline Sri Lanka & DHS, 2006-2007 & 25.0 & 1.0 & 11.7 & 22.2 & 9.3 & 8.1 & 0.4 & 0.0 & 22.3 & 68.0 \\
\hline Timor-Leste* & DHS, 2009-2010 & 3.7 & 0.0 & 7.8 & 71.7 & 5.9 & 0.9 & 3.7 & 0.0 & 6.4 & 22.3 \\
\hline Thailand & $\mathrm{NS}, 2009$ & 29.9 & 1.1 & 44.2 & 17.7 & 1.1 & 2.9 & 0.5 & 0.4 & 2.1 & 79.6 \\
\hline Vietnam & MICS, 2010-2011 & 5.0 & 0.1 & 13.1 & 2.2 & 40.1 & 16.4 & 0.3 & 0.0 & 22.8 & 77.8 \\
\hline \multicolumn{12}{|c|}{ Eastern Europe/Central Asia } \\
\hline Albania* & DHS, 2008-2009 & 4.3 & 0.0 & 2.3 & 1.0 & 1.3 & 5.8 & 0.0 & 0.1 & 85.1 & 69.3 \\
\hline Armenia* & $\mathrm{DHS}, 2010$ & 0.4 & 0.0 & 2.8 & 0.0 & 18.1 & 27.6 & 0.0 & 0.2 & 50.9 & 54.9 \\
\hline Azerbaijan* & DHS, 2006 & 0.8 & 0.0 & 2.2 & 0.0 & 18.5 & 4.4 & 0.0 & 0.4 & 73.6 & 51.1 \\
\hline Belarus & MICS, 2005 & 3.4 & 0.0 & 14.6 & 0.0 & 36.1 & 24.6 & 0.0 & 0.0 & 21.2 & 72.6 \\
\hline Bosnia and Herz.* & MICS, 2011-2012 & 0.4 & 0.0 & 3.5 & 0.0 & 8.4 & 13.6 & 0.0 & 0.4 & 73.6 & 45.8 \\
\hline Georgia & RHS, 2005 & 4.7 & 0.0 & 6.8 & 0.0 & 24.5 & 18.4 & 0.0 & 1.9 & 43.8 & 47.3 \\
\hline Ukraine & DHS, 2007 & 0.9 & 0.0 & 7.4 & 0.0 & 27.3 & 36.7 & 0.0 & 0.8 & 27.0 & 66.7 \\
\hline Uzbekistan* & MICS, 2006 & 3.4 & 0.2 & 3.7 & 4.3 & 80.0 & 3.4 & 0.2 & 0.3 & 4.5 & 64.9 \\
\hline
\end{tabular}

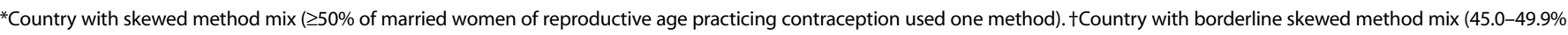

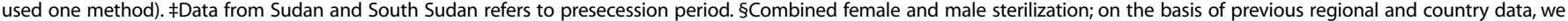

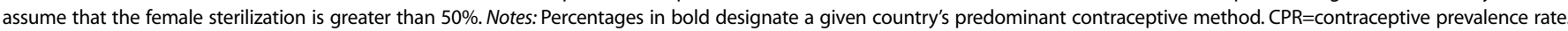

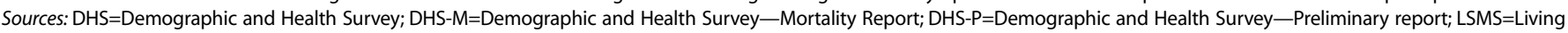

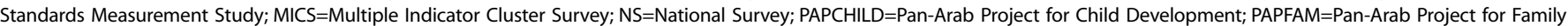
Health; RHS=Reproductive Health Survey.

index, we used a two-sample t test to compare the mean scores for two groups of countries (with and without skew). Because the years of data collection did not align exactly between the data on method mix and on the family planning program effort index, we used the 1999 effort index values for contraceptive surveys prior to 2006 and the 2009 values for surveys from 2006 onward.

In addition, we examined shifts in the use of long-acting and permanent contraceptives by country; long-acting and permanent methods are of special interest because of their high effectiveness and cost-effectiveness. Because of space limitations, we focus on female and male sterilization, the IUD and the implant; we also include the injectable, because of its growing popularity, especially in Africa.
For this analysis, we compared survey data from the latest survey conducted between 1995 and 2000 to the most recent survey conducted between 2001 and 2012 for countries with available data; the number of countries available for analysis varied by method, depending on what methods were included in the surveys conducted during the two periods. Countries with comparable surveys conducted within five years of each other were excluded (Iran and The Gambia). We rank-ordered countries for each method in terms of largest percentage-point increase to largest percentage-point decrease between surveys. Any cut-points we use to describe these surveys throughout the subsequent results section are included only to facilitate understanding of the trends in the data. 
TABLE 2. Countries with skewed method mix, by survey year and the proportion of a country's contraceptive users using its dominant method as of the latest survey

\begin{tabular}{|c|c|c|c|}
\hline \multirow[t]{2}{*}{ Method/country } & \multicolumn{2}{|l|}{ Survey year } & \multirow{2}{*}{$\begin{array}{l}\% \text { using domi- } \\
\text { nant method in } \\
\text { latest survey }\end{array}$} \\
\hline & Previous & Latest & \\
\hline \multicolumn{4}{|l|}{ Traditional } \\
\hline Albania & 2002 & 2010 & 85.1 \\
\hline Armenia & 2005 & 2005 & 50.9 \\
\hline Azerbaijan & 2001 & 2006 & 73.6 \\
\hline Bosnia-Herzegovinat & 2000 & 2011-2012 & 73.6 \\
\hline Congo-Brazzavillet & 2005 & 2011-2012 & 53.4 \\
\hline Dem.Rep. of Congo & 2001 & 2010 & 63.3 \\
\hline Serbia*,$\dagger$ & 2000 & 2010 & 64.0 \\
\hline \multicolumn{4}{|l|}{ Female sterilization } \\
\hline Dominican Republic & 2002 & 2007 & 65.5 \\
\hline India & 1998-1999 & 2005-2006 & 65.7 \\
\hline Mexico* & 2003 & 2006 & 58.3 \\
\hline \multicolumn{4}{|l|}{ Pill } \\
\hline Algeria & 1995 & 2006 & 77.4 \\
\hline Mauritania* & $2000-2001$ & 2007 & 62.0 \\
\hline Morocco§ & 1995 & 2003-2004 & 66.7 \\
\hline Niger* & 1998 & 2011 & 67.5 \\
\hline Philippines* & 2003 & 2011 & 54.5 \\
\hline Sudan & 1993 & 2006 & 75.6 \\
\hline Zimbabwe & 1999 & 2011 & 71.1 \\
\hline \multicolumn{4}{|l|}{ IUD } \\
\hline Egypt & 2000 & 2008 & 62.0 \\
\hline Kazakhstan & 1999 & 2010-2011 & 65.0 \\
\hline Kyrgyz Republic & 1997 & $2005-2006$ & 68.7 \\
\hline North Korea*,$\dagger$ & 2002 & na & 73.5 \\
\hline Tajikistant & 2005 & 2012 & 67.0 \\
\hline Turkmenistan & 2000 & na & 74.1 \\
\hline Uzbekistan & 2002 & 2006 & 80.0 \\
\hline \multicolumn{4}{|l|}{ Injectable } \\
\hline Ethiopia* & 2000 & 2011 & 73.0 \\
\hline Haiti* & 2000 & 2012 & 67.8 \\
\hline Indonesia* & $2002-2003$ & 2012 & 51.9 \\
\hline Malawi & 2000 & 2010 & 57.6 \\
\hline Myanmar* & 1997 & 2010 & 60.2 \\
\hline Rwanda* & 2000 & 2010 & 51.6 \\
\hline Timor-Leste† & 2003 & 2010 & 71.7 \\
\hline \multicolumn{4}{|l|}{ Condoms } \\
\hline Botswana* & 2000 & $2007-2008$ & 68.8 \\
\hline South Sudan*, $†$ & na & 2006 & 73.5 \\
\hline
\end{tabular}

*Newly skewed since 2005 , based on the latest available survey data. tWere not examined in Sullivan et al.'s 2006 article. ¥Mexico's national survey combines male and female sterilization; based on regional data, we assume that female sterilization surpassed $50 \%$. \$2003-2004 survey not examined in Sullivan et al.'s 2006 article and is the latest available data source as of writing. Note: na=not applicable.

\section{RESULTS}

\section{Current Status and Recent Changes in Method Skew}

- Countries with method skew. Of the countries included in this analysis, 33 (30\%) had a skewed method mix (Table 1, pages 146-147). In Sullivan et al.'s 2006 article, 34 of 96 countries (35\%) had a skewed method mix, ${ }^{11}$ which suggests that there has been a modest shift toward a more balanced method mix overall; however, the dynamics for specific methods changed in many countries.

Among the countries with a skewed method mix after 2005, the preferred method was evenly distributed across four main types: seven countries each for traditional methods, the pill, the IUD and the injectable (Table 2). In addition, three countries were skewed toward female steriliza- tion and two countries toward condoms. Countries with a mix skewed toward traditional methods were largely from Eastern Europe and Central Asia (Albania, Armenia, Azerbaijan, Bosnia-Herzegovina and Serbia); countries with a mix skewed toward the pill were mostly in Sub-Saharan Africa (Mauritania, Niger, Sudan and Zimbabwe) and northern Africa (Algeria and Morocco); and countries in which the IUD was the predominant method were mostly from Central Asia (Kazakhstan, Kyrgyz Republic, Tajikistan, Turkmenistan and Uzbekistan). No clear pattern emerged for countries favoring the injectable, as three were in SubSaharan Africa (Ethiopia, Malawi and Rwanda), three were in Asia (Indonesia, Myanmar and Timor-Leste), and one was Haiti. The three countries with predominant use of female sterilization were the Dominican Republic, India and Mexico, while the two countries skewed toward condoms were Botswana and South Sudan.

When we compared method skew before and after 2005, 20 countries had a method mix that was still skewed; Rwanda was the only country with a still-skewed method mix that switched predominant methods (from traditional to the injectable) between periods. In 13 countries, the method mix was newly skewed The injectable was the primary method in five of these countries (Ethiopia, Haiti, Indonesia, Myanmar and Rwanda). The pill was the dominant method in three countries (Mauritania, Niger and the Philippines); as of the latest survey, the proportions of women using the pill in those countries ranged from $55 \%$ in the Philippines to $68 \%$ in Niger. Both Botswana and South Sudan were newly skewed toward condom use; within eight years, the proportion of women in Botswana relying on the condom rose from $37 \%$ to $69 \%$. In 2003, female sterilization was already common among married women of reproductive age in Mexico (representing 46\% of all method use), and within three years, its share of all use had grown to more than $50 \%$. Serbia was the only country recently skewed toward traditional use (64\%).

- Countries no longer skewed. Sixteen countries examined by Sullivan et al. that had a skewed method mix based on data available as of 2005 no longer had a skewed mix based on their later survey (Table 3). Eleven of those-eight from Sub-Saharan Africa (Benin, Cameroon, Central African Republic, Chad, Côte d'Ivoire, Gabon, Madagascar and Togo), two from Central Asia and Eastern Europe (Georgia, Romania) and one from the Middle East (Yemen)-had moved away from traditional method use. Other countries reduced reliance on female sterilization (Brazil and Panama), the pill (Liberia) or the IUD (Cuba and Moldova)

In addition, 15 countries were borderline skewed, defined as having a single contraceptive method relied on by $45.0-49.9 \%$ of users (Table 1 ). The injectable was the predominant method in eight of the borderline-skewed countries, all of which were in Sub-Saharan Africa (Burundi, Chad, Kenya, Madagascar, Mozambique, Sierra Leone, South Africa and Uganda); according to Sullivan et al., ${ }^{11}$ Chad and Madagascar were once highly skewed toward traditional methods and, like Rwanda, have increasingly 
adopted the injectable. Other countries were borderline skewed toward the pill (Central African Republic and Chile), the IUD (China, Syria and Tunisia) and traditional methods (Mauritius and Romania).

\section{Correlates of Method Skew}

Of the four variables tested-geographic region, family planning effort index, modern contraceptive prevalence and human development index-only geographic region showed any evidence of an association with method skew. A greater proportion of countries in Eastern Europe and Central Asia than of those in other regions had a skewed method mix (56\% vs. 15-33\%; Web Appendix Table 1), but the difference was only marginally significant ( $p=.09$ ). The methods causing the skew varied markedly by region.

In analyses of family planning program effort index, countries with a skewed method mix had a lower mean total score than nonskewed countries (47.5 vs. 49.6 out of 100), but the difference was not significant ( $p=.42$ ); the mean access score for the countries with a skewed mix was less than that for countries without (46.4 vs. 50.5), but again the difference was not significant $(\mathrm{p}=.18)$. For modern contraceptive prevalence and human development index, there was no evidence of a trend and no findings were significant.

\section{Shifts in Use of Long-Acting and Permanent Methods}

- Female and male sterilization. Of the 84 countries examined, the proportion of married women of reproductive age practicing contraception who rely on female sterilization decreased in far more countries than it increased (54 vs. 28; Web Appendix Table 2). Brazil, Swaziland, Mozambique and Chad had the greatest decreases in the share of contraceptive use accounted for by female sterilization (11-16 percentage points), whereas Mexico, Costa Rica, Colombia, Cuba and Sudan had the greatest increases (6-11 percentage points).

The proportion of use accounted for by male sterilization was far lower than the proportion accounted for by female sterilization, often representing a small fraction of the latter. Forty-three countries reported male sterilization use; Nepal and Costa Rica were the countries where male sterilization accounted for the greatest share of use (16\% and $7 \%$, respectively). The proportion of contraceptive users relying on male sterilization decreased in more countries than it increased (29 vs. 13); the share of use accounted for by male sterilizations declined by at least three percentage points in three countries (China, Myanmar and Nepal) and increased by at least three percentage points in three countries (Brazil, Colombia and Costa Rica). In short, these results demonstrate a move away from permanent sterilization in the past decade in the majority of countries with available data.

*Many surveys from the 1995-2000 period did not list implants as a separate category; thus, it was not possible for us to assess changes over time.

\begin{tabular}{|c|c|c|c|}
\hline \multirow[t]{2}{*}{ Method/country } & \multicolumn{2}{|l|}{ Survey year } & \multirow{2}{*}{$\begin{array}{l}\text { \% using domi- } \\
\text { nant method in } \\
\text { latest survey }\end{array}$} \\
\hline & Previous & Latest & \\
\hline \multicolumn{4}{|l|}{ Traditional } \\
\hline Benin & 2000 & 2011-2012 & 37.0 \\
\hline Cameroon & 1998 & 2011 & 37.8 \\
\hline Central African Rep. & 2000 & 2006 & 24.6 \\
\hline Chad & 1996-1997 & 2004 & 15.8 \\
\hline Cote d'Ivoire & 1998-1999 & 2006 & 27.3 \\
\hline Gabon & 2000 & 2012 & 27.0 \\
\hline Georgia & 1999-2000 & 2005 & 43.8 \\
\hline Madagascar & 1997 & 2009 & 27.2 \\
\hline Romania & 1999 & 2004 & 45.7 \\
\hline Togo & 1998 & 2006 & 32.1 \\
\hline Yemen & 1997 & 2006 & 7.7 \\
\hline \multicolumn{4}{|l|}{ Female sterilization } \\
\hline Brazil & 1996 & 2006 & 36.2 \\
\hline Panama & 1984 & 2009 & 34.6 \\
\hline \multicolumn{4}{|l|}{ Pill } \\
\hline Liberia & 1986 & 2007 & 33.0 \\
\hline \multicolumn{4}{|l|}{ IUD } \\
\hline Cuba & 2000 & 2006 & 33.6 \\
\hline Moldova & 1997 & 2005 & 38.4 \\
\hline
\end{tabular}

Note: Countries no longer skewed since 2005 , based on the latest available survey data.

-IUD. Among the 92 countries in which IUD use was reported, the proportion of contraceptive users relying on the IUD decreased in more than twice as many countries as it increased (65 vs. 26; Web Appendix Table 3). Russia had the largest decrease in IUD use-a 42 percentage-point drop between 1996 and 2007-followed by Cuba, with a drop of 26 points over 10 years. The IUD's share of use decreased by more than 10 percentage points in eight other countries (Bolivia, Belarus, Indonesia, Iraq, Moldova, Nicaragua, Peru and Vietnam). Lebanon had the largest increase in IUD use (12 percentage points), followed by Burundi and Ethiopia (six percentage points each); China, Somalia and Sudan each increased their reliance on the IUD by at least four percentage points.

- Implant. Implant use was reported in 51 countries, according to the most recent surveys since 2006 (Web Appendix Table 4).* The majority of countries where the implant's share of contraceptive use was highest were in SubSaharan Africa (Burkina Faso, Rwanda, Ethiopia, Uganda,

TABLE 4. Number of countries, by change in use of longacting and permanent methods among married women of reproductive age between 1995-2000 and 2001-2012

\begin{tabular}{lllll} 
Method & $\begin{array}{l}\text { Increased } \\
\text { use }\end{array}$ & $\begin{array}{l}\text { Decreased } \\
\text { use }\end{array}$ & No change & Total \\
\hline Female sterilization & 28 & 54 & 2 & 84 \\
Male sterilization & 13 & 29 & 1 & 43 \\
IUD & 26 & 65 & 1 & 92 \\
Injectable & 64 & 15 & 5 & 84
\end{tabular}

Notes: This table excludes the implant, because of nonavailability of method-specific data in earlier period. Change was measured using data from the last available survey in each period. 
Senegal and Tanzania). Countries where the method's share of use was lowest were in Latin America (Brazil, Peru, Cuba and El Salvador).

-Injectable. Of the 84 countries examined, the proportion of users relying on the injectable rose in far more countries than it decreased (64 vs. 15; Web Appendix Table 5). A majority of those were in Sub-Saharan Africa, where seven had increases of more than 25 percentage points; Chad had the highest increase (42 percentage points), followed by Rwanda and Ethiopia (36 and 34, respectively).

The results from this analysis of shifts in method use between surveys conducted in 1995-2000 and 2001-2012 are summarized in Table 4.

\section{DISCUSSION}

As previously mentioned, our analysis of method skew builds on the 2006 article by Sullivan et al.," however, our analysis of shifts in method mix relates to previous research by Darroch examining contraceptive use data at the regional and subregional level from 1950 to 2010 and shifts in contraceptive trends worldwide over time. ${ }^{15}$ Darroch found a slight increase in female sterilization use and a dramatic increase in injectable use, but a sharp decline in use of male sterilization. In addition, she reported an increase in long-acting reversible method use (the IUD, injectable and implant), a decline in pill use and little change in use of condoms and vaginal methods. Overall, the shifts in contraceptive use we report in this article were similar, except our analysis indicates that the proportion of users relying on female sterilization decreased in far more countries than it increased.

The number and geographic location of countries reporting a method skew toward traditional methods has changed over time. In general, fewer countries showed a skew toward traditional methods in their latest survey studied than previously. And although many Eastern European and Central Asian countries were still skewed toward these methods, far fewer Sub-Saharan African countries were. In the vast majority of cases, CPRs have increased and, with those increases, contraceptive use has shifted away from traditional methods toward modern methods. Although this is promising, use of long-acting and permanent methods continues to lag in these counties. There are a number of possible explanations for these shifts in SubSaharan Africa. Access to and use of contraceptives have increased over time, ${ }^{21}$ with local governments and international donors showing renewed commitment to family planning in Sub-Saharan Africa. ${ }^{3}$ Also, the benefits of specific methods-such as the injectable (discreet method use) or condoms (dual protection against pregnancy and STIs)-may have lured clients from traditional methods to modern ones.

Traditional methods continue to dominate the method mix in a number of Eastern European and Central Asian countries. Many of the former states of the Soviet Union have historically suffered from a lack of access to modern methods. Even as these countries have made the transition from socialist to market-based economies, knowledge of and access to modern contraceptives remain low in many, and traditional methods (predominantly withdrawal) are commonly used in combination with induced abortion. $^{22-24}$

A handful of countries remain skewed toward the pill. In Algeria, Morocco, Sudan and Zimbabwe, this preference is related to a historic dominance of the method, combined with women's desire for a method that does not require their visiting a medical facility and their desire to space rather than limit births. ${ }^{11}$ Mauritania, a country newly skewed toward the pill, has a very low CPR, coupled with a rate of unmet need for spacing or limiting of approximately $30 \%$, which suggests that greater access to a constellation of modern methods is needed there. ${ }^{25}$ Niger also has a low CPR; contraceptive methods have been offered there for free since 2002, yet use remains low. ${ }^{26}$ In the Philippines, contraceptive method use has shifted away from traditional methods toward the pill, which has resulted in a skew toward that method. Since 2004, reductions in public funds (including the United States Agency for International Development's phasing out of funds for contraceptives from 2004 to 2008) have increased women's reliance on private pharmacies to obtain contraceptives ${ }^{27}$ access to modern methods limited to pharmacies may explain heavy reliance on a short-acting method such as the pill.

The number of countries with a method mix skewed toward the injectable has increased dramatically over time. In 2006, only Malawi had a heavy reliance on the injectable; since then, six other countries have become skewed toward the method. The three Sub-Saharan African countries on the list (Ethiopia, Malawi and Rwanda) have been celebrated as family planning success stories, given their recent sharp increases in contraceptive prevalence rates and decreases in unmet need. ${ }^{28}$ In all three, demand for and access to family planning information and services have expanded, in part because lower-level cadres of health workers have been trained and authorized to provide services at the community level.

The dominance of the injectable in the method mix can be viewed as generally positive if its use supplants use of less effective methods, overall use is increasing and the method mix is meeting contraceptive needs. In SubSaharan Africa, where there is a growing unmet need for limiting, ${ }^{29}$ it will be important to continue to track these trends to ensure that the methods offered meet the needs of women who do not want more children. In Indonesia, injectable use has risen over time among spacers, younger limiters and older limiters, while use of other short-acting methods and long-acting and permanent methods has decreased among these groups. ${ }^{14}$ These changes in method mix are cause for concern-particularly because limiters are using less effective, short-acting methods, which may lead to increases in unintended pregnancy. A slightly different pattern was found in Haiti, where use of long-acting and permanent methods has decreased as use of the in- 
jectable has increased among the three groups. ${ }^{14}$

Myanmar has suffered from prolonged civil unrest, which has led to lower access to and use of modern contraceptives in remote areas with civil conflict. ${ }^{30}$ The country's reproductive health program has focused on birthspacing to promote maternal and child health. Over time, the favored method among women has shifted from the pill to the injectable, perhaps because of the injectable's availability and its convenience of use (no daily action required). ${ }^{31}$

Timor-Leste gained independence from Indonesia in 2002, and as it has struggled to build its health program, it has grappled with the cultural value placed on large families. ${ }^{32}$ The country's method mix has become skewed toward the injectable, perhaps because it is a good fit in a context where family planning is integrated into maternal and child health programs for the purposes of spacing rather than limiting.

The Dominican Republic, India and Mexico have a method mix skewed toward female sterilization. Given that female sterilization is a permanent method, its predominance in the method mix is cause for concern if women are pressured to adopt the method or they lack access to other methods. The Dominican Republic has a long history of offering female sterilization: The country's "mature" sterilization program (i.e., sterilization services are a major component of the program, and access is not restricted by legal or social barriers) and the high proportions of women choosing sterilization at relatively young ages contribute to the dominance of the method in its method mix. ${ }^{33}$ In India, the high proportion of women using female sterilization continues to be a concern, because of the potential for sterilization regret-particularly among women who are young, have lost a child or have had only female children. ${ }^{34}$ The historic use of method-specific targets in Mexico's family planning program, with a focus on long-acting and permanent methods, has resulted in the country's method mix now being skewed toward female sterilization. ${ }^{35}$ By contrast, Brazil and Panama have experienced substantial shifts in their method mix and are no longer skewed toward female sterilization. In fact, the proportion of users relying on female sterilization in those two countries has dropped to around one-third, reflecting a more balanced method mix.

Botswana and South Sudan have a method mix skewed toward condoms. Although Botswana's skewed mix makes sense in the light of the country's high HIV prevalence over the last two decades, many women there need a method that is more effective than condoms at preventing pregnancy. ${ }^{36}$ South Sudan has a large family norm and an extremely low CPR. ${ }^{37}$ According to a 2006 Reproductive Health/Family Planning Assessment report, family planning services there are limited, emphasize natural family planning methods, often supply only condoms and cannot be used without permission of husbands. ${ }^{38}$

No country had a method mix skewed toward the implant, possibly because of the method's relatively recent introduction into national family planning programs.
The implant likely offers the greatest potential to improve method mix diversity in the short and medium terms. With the introduction of new implants, such as Jadelle and Implanon, use of the method has grown rapidly, especially in Sub-Saharan African countries (Burkina Faso, Ethiopia, Rwanda, Senegal, Tanzania and Uganda), where implant use constitutes $7-21 \%$ of the method mix. Recent decreases in the price of newer implants on the international market have given even more impetus for their use. Moreover, innovative and highly effective service delivery models-such as mobile outreach and social franchising using vouchers for implants (and IUDs)-are proving to be highly effective in helping to satisfy strong demand for both limiting and spacing. ${ }^{39}$

Skewed method mix is not a definitive indicator of lack of choice or of provider bias. Rather, it is a potential red flag, worthy of further investigation at the country level. If the preference reflects cultural or societal norms (in the presence of reasonable access to a range of contraceptives), then there is no reason for concern. By contrast, if the predominance of a single method results from lack of access to multiple methods or provider bias, then choice is compromised. $^{11}$

The advantage of using skewed method mix as a red flag lies in the fact that it is readily available from standardized data sets, easy to calculate and intuitive. Using it, we identified $30 \%$ of countries as warranting further investigation into whether lack of availability of a range of contraceptives, provider bias or societal preference are obstacles to women's access to, and choice of, the contraceptive method they would prefer.

Is it possible for countries to change strongly entrenched method skew? We know of no rigorous evaluation on this question; however, the answer appears to relate to the reason for the skew. Countries that have had limited access to contraception have been able to reduce reliance on a single method (e.g., traditional methods in Eastern Europe and Sub-Saharan Africa, the IUD in Cuba) by introducing other methods. The results are less promising, however, in cases involving provider bias or cultural preference. In the late 1990s, the Morocco Ministry of Health made explicit efforts to encourage use of the IUD by providing training to its health personnel, yet these efforts have done little to change the overriding preference for the pill. ${ }^{40}$ Similarly, in the Dominican Republic, government and nongovernmental programs offer a range of contraceptives, but the strong preference for female sterilization persists.

\section{Limitations}

We acknowledge several limitations in the current analysis. First, the percentage distribution for method mix can show dramatic-possibly misleading-changes in countries in which overall contraceptive prevalence is low; results for method skew or change in method use should be interpreted with caution for such countries. Second, given the 4-5-year interval between surveys such as the DHS, as well as additional time for the actual publication of data, 
these findings may not fully capture recent changes in contraceptive choice. Third, given the "graduation" of certain countries-especially in Latin America and Asia-from the DHS program, not all countries collect contraceptive use data on a regular basis, and thus there may be a bias related to the countries available for inclusion in the analysis. Finally, the analysis draws data from a variety of sources that may use different methods to collect and code the data.

\section{CONCLUSIONS}

This article updates the current status of contraceptive method skew in low- and middle-income countries. In addition to summarizing global trends (such as increased use of the injectable, and decreased use of permanent methods and the IUD), it explores the reasons for method skew in specific countries. The statistical analyses show a marginally significant relationship between geographic region and method skew, with Eastern Europe and Central Asia having the highest percentage of countries with a skewed method mix (56\%). Given the relatively low proportion of Latin American and Caribbean countries with a skewed method mix (15\%), one might attribute this difference to the maturity of programs. Yet, there was no evidence of a relationship between the prevalence of modern contraceptive use and method skew.

Whereas future research should continue to monitor trends worldwide, Sub-Saharan Africa is the region most likely to experience dramatic changes in the coming decade. Multiple factors will influence contraceptive uptake, contraceptive choice and method skew: increasing government support for family planning, renewed investment by international donors, improving family planning service delivery, increased availability of methods (especially implants and injectables), high levels of unmet need intensified by urbanization, and changing social norms regarding family size. ${ }^{1}$ However, lack of political will, weak delivery systems, and sociocultural resistance to family planningin general and to permanent methods in particular-will also factor into these dynamics. This analysis shows a shift in a positive direction toward a more balanced method mix; yet, with $30 \%$ of countries still exhibiting method skew, continued tracking of this indictor is warranted.

\section{REFERENCES}

1. Cleland J et al., Family planning: the unfinished agenda, Lancet, 2006, 368(9549):1810-1827.

2. Bongaarts J et al., Family Planning Programs for the 21st Century: Rationale and Design, New York: Population Council, 2012

3. London Summit on Family Planning, Summaries of Commitments, 2013, <http://www.londonfamilyplanningsummit.co.uk/ COMMITMENTS_090712.pdf>, accessed Sept. 2, 2013.

4. Hardee K et al., Voluntary Family Planning Programs that Respect, Protect, and Fulfill Human Rights: A Conceptual Framework, Washington, DC: Futures Group, 2013

5. Kim YM et al., Promoting informed choice: evaluating a decisionmaking tool for family planning clients and providers in Mexico, International Family Planning Perspectives, 2005, 31(4):162-171.

6. Jain AK et al., Evaluation of an intervention to improve quality of care in family planning programme in the Philippines, Journal of Biosocial
Science, 2012, 44(1):27-41.

7. RamaRao $\mathrm{S}$ et al, The link between quality of care and contraceptive use, International Family Planning Perspectives, 2003, 29(2):76-83.

8. Bessinger RE and Bertrand JT, Monitoring quality of care in family planning programs: a comparison of observations and client exit interviews, International Family Planning Perspectives, 2001, 27(2):63-70.

9. Blanc AK, Curtis SL and Croft TN, Monitoring contraceptive continuation: links to fertility outcomes and quality of care, Studies in Family Planning, 2002, 33(2):127-140.

10. Bruce J, Fundamental elements of the quality of care: a simple framework, Studies in Family Planning, 1990, 21(2):61-91.

11. Sullivan TM et al., Skewed contraceptive method mix: why it happens, why it matters, Journal of Biosocial Science, 2006, 38(4):501-521.

12. Reproductive Health Supplies Coalition, Contraceptive Implants: Product Brief Caucus on New and Underused Reproductive Health Technologies, 2012, <http://www.rhsupplies.org/fileadmin/user upload/Caucus_on_New_RH_technologies/rhsc-brief-contraceptiveimplants_A4.pdf>, accessed Sept. 2, 2013

13. Barnes J et al., Total Market Initiatives for Reproductive Health, Bethesda, MD, USA: Abt Associates, 2012

14. Sutherland EG, Otterness C and Janowitz B, What happens to contraceptive use after injectables are introduced? An analysis of 13 countries, International Perspectives on Sexual and Reproductive Health, 2011, 37(4):202-208.

15. Darroch JE, Trends in contraceptive use, Contraception, 2013, 87(3):259-263

16. World Bank, Data: Country and Lending Groups, 2012, <http://data. worldbank.org/about/country-classifications/country-and-lendinggroups>, accessed Aug. 14, 2014.

17. World Bank, Data: Population Size, 2011, <http://data.worldbank. org>, accessed Aug. 14, 2014

18. United Nations, Department of Economic and Social Affairs, Population Division, World Contraceptive Use 2012, 2012, <http://www. un.org/esa/population/publications/WCU2012/MainFrame.html>, accessed Aug. 14, 2014.

19. Fabic MS and Choi Y, Assessing the quality of data regarding use of the lactational amenorrhea method, Studies in Family Planning, 2013, 44(2):205-221.

20. Arévalo M, Jennings V and Sinai I, Efficacy of a new method of family planning: the Standard Days Method, Contraception, 2002, 65(5):333-338

21. Alkema L et al., National, regional, and global rates and trends in contraceptive prevalence and unmet need for family planning between 1990 and 2015: a systematic and comprehensive analysis, Lancet 2013, 381(9878):1642-1652.

22. Westoff CF et al., Contraception-abortion connections in Armenia DHS Analytical Studies, Calverton, MD, USA: ORC Macro, 2002, No. 6

23. Janevic T et al., Individual and community level socioeconomic inequalities in contraceptive use in 10 newly independent states: a multilevel cross-sectional analysis, International Journal for Equity in Health, 2012, 11(1):69.

24. Kragelund Nielsen K et al., Key barriers to the use of modern contraceptives among women in Albania: a qualitative study, Reproductive Health Matters, 2012, 20(40):158-165.

25. Health Policy Project, Achieving the MDGs: the Contribution of Family Planning: Mauritania, Washington, DC: Futures Group, 2011

26. Potts $\mathrm{M}$ et al., Niger: too little, too late, International Perspectives on Sexual and Reproductive Health, 2011, 37(2):95-101.

27. Guttmacher Institute, Facts on barriers to contraceptive use in the Philippines, In Brief, New York: Guttmacher Institute, 2010.

28. USAID Africa Bureau et al., Three Successful Sub-Saharan Africa Family Planning Programs: Ethiopia, Malawi, Rwanda, Washington, DC: USAID, 2012

29. Van Lith LM, Yahner M and Bakamjianc L, Women's growing de- 
sire to limit births in sub-Saharan Africa: meeting the challenge, Global Health: Science and Practice, 2013, 1(1):97-107.

30. Hobstetter $\mathrm{M}$ et al., Separated by Borders, United in Need: An Assessment of Reproductive Health on the Thailand-Burma Border, Cambridge, MA, USA: Ibis Reproductive Health, 2012.

31. Taw NP, Country Report on 2007 Fertility and Reproductive Health Survey, Yangon, Myanmar: Union of Myanmar, Ministry of Immigration and Population, Department of Population and United Nations Population Fund (UNFPA), 2009

32. Thompson $S$ and Mercer MA, Integrating Child Spacing with Maternal Care in Timor-Leste, Dili, Timor-Leste: Health Alliance International (HAI), 2009

33. EngenderHealth, Contraceptive Sterilization: Global Issues and Trends, New York: EngenderHealth, 2002.

34. Singh A et al., Sterilization regret among married women in India: implications for the Indian national family planning program, International Perspectives on Sexual and Reproductive Health, 2012, 38(4):187-195.

35. Potter JE, The persistence of outmoded contraceptive regimes: the cases of Mexico and Brazil, Population and Development Review, 1999, 25(4):703-739.

36. Kraft JM et al., Use of dual protection in Botswana, Studies in Family Planning, 2009, 40(4):319-328.

37. Aveyard R and Alfred A, Understanding Knowledge, Attitudes, Beliefs, and Practices Around Reproductive, Maternal, Neonatal, and Child Health in South Sudan, London: BBC Media Action, 2013.

38. Government of South Sudan and Extending Service Delivery Project, Reproductive Health/Family Planning Service Provision for Returning Populations to South Sudan: Assessment Findings \& Recommendations, 2006, <http://www.esdproj.org/site/DocServer/ Sth_Sudan_Situation_Atssessment_Report___FINAL_09-25-06_. pdf?docID=321>, accessed Aug. 14, 2014.

39. Jacobstein R and Stanley H, Contraceptive implants: providing better choice to meet growing family planning demand, Global Health: Science and Practice, 2013, 1(1):11-17.

40. Ministry of Health, Kingdom of Morocco and the EVALUATION Project/Tulane University, The Dynamics of the Moroccan Family Planning Program, Chapel Hill, NC, USA: The EVALUATION Project, 1998.

\section{RESUMEN}

Contexto: La mezcla de métodos-la distribución porcentual de usuarios de anticonceptivos por método en un determinado país-es una medida que refleja la disponibilidad de un conjunto diverso de métodos anticonceptivos. Una mezcla sesgada de métodos-una mezcla en la que el 50\% o más de los usuarios de anticonceptivos dependen de un solo método-podría ser causa de preocupación en tanto signo de insuficiencia de métodos alternativos o de sesgo del proveedor. Los cambios en la mezcla de métodos son importantes para los países individuales, donantes y académicos que estudian la dinámica anticonceptiva.

Métodos: Para determinar los patrones actuales y cambios recientes en la mezcla de métodos, se examinaron 109 países de bajos y medianos ingresos. Se utilizó una variedad de métodos estadísticos para probar cuatro factores como correlatos de la mezcla sesgada de métodos: región geográfica, índice de esfuerzo del programa de planificación familiar, tasa de prevalencia de uso de anticonceptivos modernos e índice de desarrollo humano. Se condujo un análisis de cambios en la dependencia en la esterilización femenina y masculina, DIU, implantes e inyectables para los países con datos disponibles.

Resultados: De los 109 países incluidos en este análisis, el $30 \%$ tuvo una mezcla sesgada de métodos-una disminución modesta respecto al 35\% obtenido en un análisis realizado en 2006. Solamente una región geográfica mostró alguna correlación con el sesgo de métodos, pero solo tuvo una significancia marginal. La proporción de usuarios que dependian de la esterilización femenina, la esterilización masculina o el DIU disminuyó en muchos más países que en los que aumentó; el patrón fue inverso en el caso de los inyectables.

Conclusión: El sesgo en la mezcla de métodos no es un indicador definitivo de la falta de opciones anticonceptivas o del sesgo del proveedor; pero puede que refleje preferencias culturales. En países con una mezcla sesgada de métodos, se justifica la investigación para determinar la causa.

\section{RÉSUMÉ}

Contexte: L'éventail de méthodes-représentant les pourcentages de répartition, par méthode, des utilisatrices de la contraception dans un pays donné-est une mesure qui reflète la disponibilité d'une gamme de méthodes contraceptives. Une distribution asymétrique-dans laquelle $50 \%$ ou plus des utilisatrices pratiquent une même méthode-pourrait être préoccupante en ce qu'elle pourrait être signe d'insuffisance d'autres méthodes ou de biais des prestataires. Les variations de l'éventail comptent pour les pays individuels, les donateurs et les chercheurs qui étudient la dynamique contraceptive.

Méthodes: Afin de déterminer les tendances actuelles et l'évolution récente de l'éventail de méthodes, 109 pays à revenu faible à intermédiaire ont été examinés. Différentes méthodes statistiques ont été utilisées pour tester quatre facteurs de corrélation d'éventail asymétrique: la région géographique, l'indice d'effort programmatique de planification familiale, le taux de prévalence de la contraception moderne et l'indice de développement humain. Les changements survenus au niveau du recours à la stérilisation féminine et masculine, au stérilet, aux implants et aux injectables ont été évalués pour les pays disposant de données pertinentes.

Résultats: Trente pour cent des 109 pays soumis à l'analyse présentent un éventail de méthodes asymétrique-en légère baisse par rapport aux $35 \%$ observés en 2006. Seule la région géographique est en corrélation avec l'asymétrie, mais dans une mesure marginalement significative seulement. La proportion du recours à la stérilisation féminine, la stérilisation masculine ou au stérilet diminue dans un bien plus grand nombre de pays que celui des pays où elle augmente. La tendance est inverse pour l'injectable.

Conclusion: L'asymétrie de l'éventail de méthodes n'est pas un indicateur définitif de manque de choix contraceptif ou de biais des prestataires; elle peut aussi refléter les préférences culturelles. Dans les pays présentant un éventail asymétrique, la recherche se justifie pour en identifier la cause.

Author contact: bertrand@tulane.edu 
WEB APPENDIX TABLE 1. Percentage of countries with a skewed method mix, by geographic region, and number of countries with skewed mix, by region, according to method

\begin{tabular}{|c|c|c|c|c|c|c|c|c|}
\hline \multirow[t]{2}{*}{ Region } & \multirow{2}{*}{$\begin{array}{l}\text { No.of } \\
\text { countries }\end{array}$} & \multirow{2}{*}{$\begin{array}{l}\% \text { of countries } \\
\text { with skewed } \\
\text { mix }\end{array}$} & \multicolumn{6}{|c|}{ No.of countries with skewed mix, by predominant method } \\
\hline & & & Traditional & $\begin{array}{l}\text { Female } \\
\text { sterilization }\end{array}$ & Pill & IUD & Injectable & Condom \\
\hline Asia Pacific & 18 & 33.3 & 0 & 1 & 1 & 1 & 3 & 0 \\
\hline Eastern Europe/Central Asia & 18 & 55.6 & 5 & 0 & 0 & 5 & 0 & 0 \\
\hline Latin America/Caribbean & 20 & 15.0 & 0 & 2 & 0 & 0 & 1 & 0 \\
\hline Middle East/North Africa & 10 & 30.0 & 0 & 0 & 2 & 1 & 0 & 0 \\
\hline Sub-Saharan Africa & 43 & 25.6 & 2 & 0 & 4 & 0 & 3 & 2 \\
\hline Total & 109 & 30.3 & 7 & 3 & 7 & 7 & 7 & 2 \\
\hline
\end{tabular}


WEB APPENDIX TABLE 2. Changes in share of method mix accounted for by female and male sterilization between latest surveys from 1995-2000 and 2001-2012 among married women of reproductive age in 84 countries, ranked in order of percentage-point change (highest to lowest) for female sterilization

\begin{tabular}{|c|c|c|c|c|c|c|c|c|}
\hline \multirow[t]{2}{*}{ Country } & \multicolumn{3}{|c|}{ Female sterilization } & \multicolumn{3}{|c|}{ Male sterilization } & \multicolumn{2}{|c|}{ Survey year } \\
\hline & $\begin{array}{l}\text { Percentage- } \\
\text { point change }\end{array}$ & $\begin{array}{l}1995- \\
2000\end{array}$ & $\begin{array}{l}2001- \\
2012\end{array}$ & $\begin{array}{l}\text { Percentage- } \\
\text { point change }\end{array}$ & $\begin{array}{l}1995- \\
2000\end{array}$ & $\begin{array}{l}2001- \\
2012\end{array}$ & $\begin{array}{l}1995- \\
2000\end{array}$ & $\begin{array}{l}2001- \\
2012\end{array}$ \\
\hline Mexico* & 11.0 & 47.3 & 58.3 & na & na & na & 1995 & 2006 \\
\hline Costa Rica & 9.3 & 26.8 & 36.1 & 6.5 & 0.6 & 7.1 & 1999 & 2010 \\
\hline Colombia & 8.6 & 35.8 & 44.4 & 3.0 & 1.3 & 4.3 & 2000 & 2010 \\
\hline Cuba & 6.4 & 25.9 & 32.3 & 0.0 & 0.0 & 0.0 & 2000 & 2011 \\
\hline Sudan & 5.9 & 0.0 & 5.9 & 0.0 & 0.0 & 0.0 & 1999 & 2006 \\
\hline Moldova & 5.3 & 1.8 & 7.2 & 0.0 & 0.0 & 0.0 & 2000 & 2005 \\
\hline Malawi & 4.9 & 16.7 & 21.7 & -0.1 & 0.4 & 0.2 & 2000 & 2010 \\
\hline Ghana & 4.9 & 2.2 & 7.1 & 0.0 & 0.0 & 0.0 & 1999 & 2008 \\
\hline Turkey & 4.8 & 6.6 & 11.4 & 0.1 & 0.0 & 0.1 & 1998 & 2008 \\
\hline Zambia & 3.7 & 2.0 & 5.7 & -1.0 & 1.0 & 0.0 & 1999 & 2007 \\
\hline Albania & 2.7 & 1.6 & 4.3 & -0.4 & 0.4 & 0.0 & 2000 & 2009 \\
\hline Bolivia & 2.2 & 8.8 & 10.9 & 0.2 & 0.0 & 0.2 & 2000 & 2008 \\
\hline Lebanon & 2.0 & 7.1 & 9.1 & 0.0 & 0.0 & 0.0 & 1996 & 2006 \\
\hline Tanzania & 2.0 & 8.9 & 10.9 & 0.0 & 0.0 & 0.0 & 1999 & 2010 \\
\hline Algeria & 1.9 & 0.0 & 1.9 & 0.0 & 0.0 & 0.0 & 2000 & 2006 \\
\hline Belarus & 1.8 & 1.6 & 3.4 & 0.0 & 0.0 & 0.0 & 1995 & 2005 \\
\hline Mongolia & 1.6 & 2.1 & 3.7 & -0.3 & 0.3 & 0.0 & 2000 & 2005 \\
\hline Tajikistan & 1.6 & 0.6 & 2.2 & -0.3 & 0.3 & 0.0 & 2000 & 2012 \\
\hline Uzbekistan & 1.2 & 2.1 & 3.4 & 0.0 & 0.2 & 0.2 & 2000 & 2006 \\
\hline Burundi & 1.2 & 1.5 & 2.7 & -0.8 & 0.8 & 0.0 & 2000 & 2010 \\
\hline Lesotho & 0.8 & 4.4 & 5.2 & -0.3 & 0.3 & 0.0 & 2000 & 2009 \\
\hline Georgia & 0.7 & 4.0 & 4.7 & 0.0 & 0.0 & 0.0 & 2000 & 2005 \\
\hline Botswana & 0.6 & 2.8 & 3.5 & -0.3 & 0.5 & 0.2 & 2000 & 2008 \\
\hline Philippines & 0.6 & 23.1 & 23.7 & -0.2 & 0.4 & 0.3 & 2000 & 2011 \\
\hline CAR & 0.5 & 1.1 & 1.6 & 0.0 & 0.0 & 0.0 & 2000 & 2010 \\
\hline Serbia & 0.3 & 0.0 & 0.3 & 0.0 & 0.0 & 0.0 & 2000 & 2010 \\
\hline Bosnia & 0.2 & 0.2 & 0.4 & 0.0 & 0.0 & 0.0 & 2000 & 2012 \\
\hline Romania & 0.1 & 3.9 & 4.0 & 0.0 & 0.0 & 0.0 & 1999 & 2004 \\
\hline Yemen & 0.0 & 11.0 & 11.1 & -0.8 & 0.8 & 0.0 & 1997 & 2006 \\
\hline Somalia & 0.0 & 0.0 & 0.0 & 0.0 & 0.0 & 0.0 & 1999 & 2006 \\
\hline Indonesia & -0.1 & 5.3 & 5.2 & -0.4 & 0.7 & 0.3 & 19997 & 2012 \\
\hline Côte d'Ivoire & -0.1 & 0.7 & 0.6 & 0.0 & 0.0 & 0.0 & 2000 & 2011 \\
\hline Azerbaijan & -0.2 & 1.0 & 0.8 & -0.2 & 0.2 & 0.0 & 2000 & 2006 \\
\hline Kazakhstan & -0.2 & 4.7 & 4.5 & 0.0 & 0.0 & 0.0 & 1999 & 2011 \\
\hline Nigeria & -0.5 & 2.1 & 1.6 & 0.0 & 0.0 & 0.0 & 1999 & 2012 \\
\hline Madagascar & -0.5 & 3.3 & 2.8 & 0.3 & 0.0 & 0.3 & 2000 & 2009 \\
\hline Ecuador & -0.5 & 34.1 & 33.7 & 0.0 & 0.0 & 0.0 & 1999 & 2004 \\
\hline Mali & -0.6 & 4.8 & 4.2 & 0.0 & 0.0 & 0.0 & 1996 & 2006 \\
\hline Namibia & -0.8 & 19.8 & 19.0 & -1.1 & 1.9 & 0.7 & 2000 & 2007 \\
\hline Egypt & -0.8 & 2.6 & 1.7 & 0.0 & 0.0 & 0.0 & 2000 & 2008 \\
\hline Timor-Leste & -0.9 & 4.6 & 3.7 & 0.0 & 0.0 & 0.0 & 1997 & 2010 \\
\hline
\end{tabular}


WEB APPENDIX TABLE 2. continued

\begin{tabular}{|c|c|c|c|c|c|c|c|c|}
\hline \multirow[t]{2}{*}{ Country } & \multicolumn{3}{|c|}{ Female sterilization } & \multicolumn{3}{|c|}{ Male sterilization } & \multicolumn{2}{|c|}{ Survey year } \\
\hline & $\begin{array}{l}\text { Percentage- } \\
\text { point change }\end{array}$ & $\begin{array}{l}1995- \\
2000\end{array}$ & $\begin{array}{l}2001- \\
2012\end{array}$ & $\begin{array}{l}\text { Percentage- } \\
\text { point change }\end{array}$ & $\begin{array}{l}1995- \\
2000\end{array}$ & $\begin{array}{l}2001- \\
2012\end{array}$ & $\begin{array}{l}1995- \\
2000\end{array}$ & $\begin{array}{l}2001- \\
2012\end{array}$ \\
\hline Morocco & -1.0 & 5.5 & 4.5 & 0.0 & 0.0 & 0.0 & 1997 & 2004 \\
\hline Ukraine & -1.1 & 2.1 & 0.9 & 0.0 & 0.0 & 0.0 & 1999 & 2007 \\
\hline Kyrgyz Republic & -1.2 & 3.1 & 1.9 & 0.0 & 0.0 & 0.0 & 1997 & 2006 \\
\hline Pakistan & -1.3 & 25.6 & 24.3 & 0.0 & 0.0 & 0.0 & 1997 & 2008 \\
\hline Paraguay & -1.5 & 14.0 & 12.5 & 0.3 & 0.0 & 0.3 & 1998 & 2008 \\
\hline Gabon & -1.5 & 3.4 & 1.9 & 0.0 & 0.0 & 0.0 & 2000 & 2012 \\
\hline Dominican Rep. & -1.6 & 67.0 & 65.5 & 0.0 & 0.0 & 0.0 & 2000 & 2007 \\
\hline Thailand & -1.6 & 31.5 & 29.9 & -1.7 & 2.9 & 1.1 & 1997 & 2009 \\
\hline Benin & -1.6 & 2.6 & 1.0 & 0.0 & 0.0 & 0.0 & 1996 & 2012 \\
\hline Ethiopia & -2.0 & 3.8 & 1.8 & 0.0 & 0.0 & 0.0 & 2000 & 2011 \\
\hline Uganda & -2.0 & 11.9 & 9.9 & 0.3 & 0.0 & 0.3 & 1995 & 2011 \\
\hline Laos & -2.4 & 14.8 & 12.4 & 0.0 & 0.0 & 0.0 & 2000 & 2005 \\
\hline Cambodia & -2.4 & 7.2 & 4.8 & -0.9 & 0.0 & 0.0 & 2000 & 2010 \\
\hline Eritrea & -2.7 & 6.0 & 3.3 & 0.0 & 0.0 & 0.0 & 1995 & 2002 \\
\hline Zimbabwe & -3.1 & 5.0 & 1.9 & -0.2 & 0.2 & 0.0 & 1999 & 2011 \\
\hline Vietnam & -3.3 & 8.3 & 5.0 & -0.7 & 0.8 & 0.1 & 2000 & 2011 \\
\hline Niger & -3.3 & 4.5 & 1.2 & 0.0 & 0.0 & 0.0 & 2000 & 2012 \\
\hline Honduras & -3.6 & 36.2 & 32.6 & 0.3 & 0.2 & 0.5 & 1996 & 2006 \\
\hline Senegal & -3.8 & 5.4 & 1.6 & 0.0 & 0.0 & 0.0 & 1999 & 2011 \\
\hline Iraq & -4.1 & 9.9 & 5.7 & -0.3 & 0.3 & 0.0 & 2000 & 2011 \\
\hline Cameroon & -4.2 & 6.4 & 2.2 & 0.0 & 0.9 & 0.0 & 2000 & 2011 \\
\hline South Africa & -4.3 & 28.2 & 23.9 & -2.6 & 3.7 & 1.2 & 1998 & 2003 \\
\hline Bangladesh & -4.5 & 12.7 & 8.2 & 1.0 & 0.9 & 2.0 & 2000 & 2011 \\
\hline Jordan & -4.6 & 8.4 & 3.7 & 0.0 & 0.0 & 0.0 & 1997 & 2012 \\
\hline Jamaica & -4.9 & 18.7 & 13.8 & 0.0 & 0.0 & 0.0 & 1997 & 2009 \\
\hline Haiti & -4.9 & 10.2 & 5.2 & 0.3 & 0.0 & 0.3 & 2000 & 2012 \\
\hline Rwanda & -5.1 & 6.7 & 1.6 & 0.0 & 0.0 & 0.0 & 2000 & 2010 \\
\hline Kenya & -5.5 & 16.3 & 10.8 & 0.0 & 0.0 & 0.0 & 1998 & 2009 \\
\hline Perú & -5.6 & 18.2 & 12.7 & -0.2 & 0.7 & 0.5 & 2000 & 2011 \\
\hline Sri Lanka & -5.6 & 30.6 & 25.0 & -2.0 & 3.1 & 1.0 & 2000 & 2007 \\
\hline India & -5.7 & 71.4 & 65.7 & -1.9 & 4.0 & 2.0 & 1999 & 2008 \\
\hline China & -6.3 & 40.2 & 33.9 & -3.9 & 9.2 & 5.3 & 1997 & 2006 \\
\hline Tunisia & -8.0 & 17.3 & 9.3 & -0.2 & 0.2 & 0.0 & 2000 & 2006 \\
\hline Nepal & -8.2 & 38.9 & 30.6 & -4.9 & 20.6 & 15.7 & 2000 & 2011 \\
\hline Guatemala & -8.8 & 43.8 & 35.0 & -0.6 & 2.1 & 1.5 & 1999 & 2009 \\
\hline Afghanistan & -9.1 & 17.4 & 8.3 & -2.2 & 2.2 & 0.0 & 2000 & 2011 \\
\hline Nicaragua & -9.5 & 43.5 & 34.0 & -0.3 & 0.8 & 0.6 & 1998 & 2007 \\
\hline Myanmar & -9.6 & 17.5 & 7.9 & -6.1 & 7.0 & 0.9 & 1997 & 2010 \\
\hline El Salvador & -9.7 & 54.2 & 44.5 & 0.4 & 0.0 & 0.4 & 1998 & 2008 \\
\hline Chad & -11.4 & 16.7 & 5.3 & 0.0 & 0.0 & 0.0 & 2000 & 2010 \\
\hline Mozambique & -11.9 & 13.7 & 1.8 & 0.0 & 0.0 & 0.0 & 1997 & 2011 \\
\hline Swaziland & -14.0 & 22.1 & 8.1 & 0.5 & 0.0 & 0.5 & 2000 & 2010 \\
\hline Brazil & -16.3 & 52.6 & 36.2 & 2.9 & 3.4 & 6.4 & 1996 & 2006 \\
\hline
\end{tabular}

*Data for female sterilization in Mexico also include male sterilization. Notes: na=not applicable. Only the 84 countries with comparable data were included in this table. Country surveys with female sterilization that had missing values were excluded. 


\begin{tabular}{|c|c|c|c|c|c|c|c|c|c|c|c|}
\hline \multirow[t]{2}{*}{ Country } & \multirow{2}{*}{$\begin{array}{l}\text { Percentage- } \\
\text { point } \\
\text { change }\end{array}$} & \multicolumn{2}{|l|}{ IUD } & \multicolumn{2}{|c|}{ Survey year } & \multirow[t]{2}{*}{ Country } & \multirow{2}{*}{$\begin{array}{l}\text { Percentage- } \\
\text { point } \\
\text { change }\end{array}$} & \multicolumn{2}{|l|}{ IUD } & \multicolumn{2}{|c|}{ Survey year } \\
\hline & & $\begin{array}{l}1995- \\
2000\end{array}$ & $\begin{array}{l}2001- \\
2012\end{array}$ & $\begin{array}{l}1995- \\
2000\end{array}$ & $\begin{array}{l}2001- \\
2012\end{array}$ & & & $\begin{array}{l}1995- \\
2000\end{array}$ & $\begin{array}{l}2001- \\
2012\end{array}$ & $\begin{array}{l}1995- \\
2000\end{array}$ & $\begin{array}{l}2001- \\
2012\end{array}$ \\
\hline Lebanon & 11.8 & 28.9 & 40.7 & 1996 & 2006 & Zambia & -2.2 & 2.5 & 0.3 & 1999 & 2007 \\
\hline Burundi & 6.3 & 6.0 & 12.3 & 2000 & 2010 & Burkina Faso & -2.2 & 4.1 & 1.9 & 1999 & 2010 \\
\hline Somalia & 5.6 & 0.0 & 5.6 & 1999 & 2006 & Côte d'Ivoire & -2.3 & 2.9 & 0.6 & 1999 & 2011 \\
\hline Sudan & 5.3 & 0.0 & 5.3 & 1999 & 2006 & Botswana & -2.7 & 4.0 & 1.3 & 2000 & 2008 \\
\hline China & 4.3 & 43.7 & 48.0 & 1997 & 2006 & Swaziland & -2.7 & 4.4 & 1.7 & 2000 & 2010 \\
\hline Kyrgyz Rep. & 2.8 & 65.9 & 68.7 & 1997 & 2006 & Chad & -2.8 & 2.8 & 0.0 & 2000 & 2010 \\
\hline Nepal & 2.4 & 0.3 & 2.6 & 2000 & 2011 & Egypt & -2.9 & 64.9 & 62.0 & 2000 & 2008 \\
\hline Sri Lanka & 1.9 & 7.4 & 9.3 & 2000 & 2007 & Rwanda & -3.0 & 4.0 & 1.0 & 1996 & 2010 \\
\hline Benin & 1.7 & 3.3 & 5.0 & 1996 & 2012 & Tunisia & -3.0 & 49.3 & 46.3 & 2000 & 2006 \\
\hline Guinea & 1.7 & 3.3 & 5.0 & 1999 & 2012 & Guatemala & -3.4 & 5.8 & 2.4 & 1999 & 2009 \\
\hline Armenia & 1.6 & 16.5 & 18.1 & 2000 & 2010 & Mali & -3.4 & 4.8 & 1.4 & 1996 & 2006 \\
\hline Jamaica & 1.4 & 0.0 & 1.4 & 1997 & 2009 & Thailand & -3.4 & 4.6 & 1.1 & 1997 & 2009 \\
\hline Philippines & 1.4 & 7.2 & 8.5 & 2000 & 2011 & Algeria & -3.5 & 7.4 & 3.9 & 2000 & 2006 \\
\hline Albania & 1.3 & 0.0 & 1.3 & 2000 & 2009 & Kenya & -3.5 & 7.1 & 3.6 & 1998 & 2009 \\
\hline Togo & 1.2 & 1.3 & 2.5 & 2000 & 2006 & Paraguay & -3.8 & 19.4 & 15.6 & 1998 & 2008 \\
\hline Brazil & 0.9 & 1.4 & 2.4 & 1996 & 2006 & Yemen & -4.4 & 23.6 & 19.2 & 1997 & 2006 \\
\hline Cambodia & 0.6 & 5.5 & 6.2 & 2000 & 2010 & Costa Rica & -4.6 & 8.6 & 4.1 & 1999 & 2010 \\
\hline Georgia & 0.5 & 24.0 & 24.5 & 2000 & 2005 & Lesotho & -4.6 & 8.7 & 4.1 & 2000 & 2009 \\
\hline Myanmar & 0.5 & 4.1 & 4.6 & 1997 & 2010 & Kazakhstan & -4.7 & 69.8 & 65.0 & 1999 & 2011 \\
\hline Haiti & 0.3 & 0.0 & 0.3 & 2000 & 2012 & Sierra Leone & -4.9 & 4.9 & 0.0 & 2000 & 2010 \\
\hline Malawi & 0.3 & 0.4 & 0.7 & 2000 & 2010 & Senegal & -4.9 & 9.8 & 4.9 & 1999 & 2011 \\
\hline Afghanistan & 0.3 & 6.5 & 6.8 & 2000 & 2011 & Mozambique & -5.0 & 5.9 & 0.9 & 1997 & 2011 \\
\hline Azerbaijan & 0.2 & 18.3 & 18.5 & 2000 & 2006 & Pakistan & -5.2 & 14.5 & 9.4 & 1997 & 2008 \\
\hline Guinea-Bissau & 0.2 & 36.5 & 36.7 & 2000 & 2010 & Eritrea & -5.3 & 12.0 & 6.7 & 1995 & 2002 \\
\hline North Korea & 0.1 & 73.4 & 73.5 & 1997 & 2002 & Angola & -5.9 & 12.7 & 6.8 & 1996 & 2001 \\
\hline Tanzania & 0.1 & 1.8 & 1.9 & 1999 & 2010 & Uzbekistan & -6.2 & 86.2 & 80.0 & 2000 & 2006 \\
\hline India & 0.0 & 3.3 & 3.3 & 1999 & 2008 & Mexico & -6.3 & 23.7 & 17.4 & 1997 & 2006 \\
\hline Ethiopia & -0.2 & 1.3 & 1.1 & 2000 & 2011 & Colombia & -6.8 & 16.4 & 9.5 & 2000 & 2010 \\
\hline Namibia & -0.2 & 2.8 & 2.6 & 2000 & 2007 & Honduras & -6.8 & 17.0 & 10.2 & 1996 & 2006 \\
\hline Cameroon & -0.2 & 1.1 & 0.9 & 2000 & 2011 & Serbia & -8.0 & 13.4 & 5.4 & 2000 & 2010 \\
\hline Ukraine & -0.3 & 27.6 & 27.3 & 1999 & 2007 & Turkey & -8.1 & 31.3 & 23.2 & 1998 & 2008 \\
\hline Madagascar & -0.6 & 1.7 & 1.0 & 2000 & 2009 & Nigeria & -8.2 & 13.9 & 5.6 & 1999 & 2012 \\
\hline Morocco & -0.7 & 9.6 & 9.0 & 1997 & 2004 & Bosnia & -8.6 & 16.9 & 8.4 & 2000 & 2012 \\
\hline CAR & -0.9 & 0.9 & 0.0 & 2000 & 2010 & Mongolia & -9.4 & 53.6 & 44.2 & 2000 & 2005 \\
\hline Timor-Leste & -0.9 & 6.9 & 5.9 & 1997 & 2010 & Tajikistan & -9.5 & 76.5 & 67.0 & 2000 & 2012 \\
\hline Dominican Rep. & -1.0 & 3.9 & 2.9 & 2000 & 2007 & Jordan & -9.7 & 46.0 & 36.3 & 1997 & 2012 \\
\hline Niger & -1.1 & 2.3 & 1.2 & 2000 & 2012 & Peru & -10.0 & 13.5 & 3.5 & 2000 & 2011 \\
\hline Bangladesh & -1.1 & 2.3 & 1.2 & 2000 & 2011 & Vietnam & -10.3 & 50.3 & 40.1 & 2000 & 2011 \\
\hline Ecuador & -1.3 & 15.3 & 14.0 & 1999 & 2004 & Indonesia & -10.4 & 16.7 & 6.3 & 2000 & 2012 \\
\hline Ghana & -1.3 & 2.2 & 0.9 & 1999 & 2008 & Nicaragua & -10.4 & 15.2 & 4.8 & 1998 & 2007 \\
\hline Zimbabwe & -1.4 & 1.7 & 0.3 & 1999 & 2011 & Bolivia & -11.6 & 25.7 & 14.1 & 2000 & 2008 \\
\hline El Salvador & -1.4 & 2.5 & 1.1 & 1998 & 2008 & Iraq & -11.6 & 31.0 & 19.4 & 2000 & 2011 \\
\hline South Africa & -1.5 & 3.2 & 1.7 & 1998 & 2003 & Moldova & -18.3 & 56.7 & 38.4 & 2000 & 2005 \\
\hline Uganda & -1.7 & 3.4 & 1.7 & 1995 & 2011 & Belarus & -21.5 & 57.7 & 36.1 & 1995 & 2005 \\
\hline Laos & -1.8 & 9.5 & 7.7 & 2000 & 2005 & Cuba & -25.8 & 59.4 & 33.6 & 2000 & 2011 \\
\hline Romania & -1.9 & 11.4 & 9.5 & 1999 & 2004 & Russian Fed. & -42.3 & 63.1 & 20.8 & 1996 & 2007 \\
\hline
\end{tabular}


WEB APPENDIX TABLE 4. Share of method mix accounted for by implant use among married women of reproductive age in 51 countries, ranked from highest to lowest

\begin{tabular}{|c|c|c|}
\hline Country & Implant & Survey year \\
\hline Burkina Faso & 21.3 & 2010 \\
\hline Rwanda & 12.4 & 2010 \\
\hline Ethiopia & 11.9 & 2011 \\
\hline Uganda & 9.2 & 2011 \\
\hline Senegal & 8.9 & 2011 \\
\hline Tanzania & 7.2 & 2010 \\
\hline Haiti & 6.6 & 2012 \\
\hline Sierra Leone & 6.5 & 2010 \\
\hline Togo & 6.2 & 2006 \\
\hline Indonesia & 5.4 & 2012 \\
\hline Zimbabwe & 4.6 & 2011 \\
\hline Kenya & 4.3 & 2009 \\
\hline Ghana & 4.0 & 2008 \\
\hline Colombia & 3.9 & 2010 \\
\hline Madagascar & 3.9 & 2009 \\
\hline Timor-Leste & 3.7 & 2010 \\
\hline Niger & 3.6 & 2012 \\
\hline Cameroon & 3.1 & 2011 \\
\hline Malawi & 2.9 & 2010 \\
\hline Swaziland & 2.8 & 2010 \\
\hline Burundi & 2.7 & 2010 \\
\hline Guinea & 2.5 & 2012 \\
\hline Nepal & 2.4 & 2011 \\
\hline Bangladesh & 1.8 & 2011 \\
\hline CAR & 1.6 & 2010 \\
\hline Nigeria & 1.6 & 2012 \\
\hline Mali & 1.4 & 2006 \\
\hline Côte d'Ivoire & 1.2 & 2011 \\
\hline Zambia & 1.2 & 2007 \\
\hline Jamaica & 1.0 & 2009 \\
\hline Egypt & 0.9 & 2008 \\
\hline Dominican Rep. & 0.8 & 2007 \\
\hline Cambodia & 0.8 & 2010 \\
\hline Iran & 0.6 & 2002 \\
\hline Jordan & 0.5 & 2012 \\
\hline Thailand & 0.5 & 2009 \\
\hline Tunisia & 0.5 & 2006 \\
\hline Sri Lanka & 0.4 & 2007 \\
\hline Namibia & 0.4 & 2007 \\
\hline Mongolia & 0.4 & 2005 \\
\hline Costa Rica & 0.4 & 2010 \\
\hline China & 0.4 & 2006 \\
\hline Vietnam & 0.3 & 2011 \\
\hline Myanmar & 0.2 & 2010 \\
\hline Lesotho & 0.2 & 2009 \\
\hline Iraq & 0.2 & 2011 \\
\hline Uzbekistan & 0.2 & 2006 \\
\hline El Salvador & 0.1 & 2008 \\
\hline Cuba & 0.1 & 2011 \\
\hline Peru & 0.1 & 2011 \\
\hline Brazil & 0.1 & 2006 \\
\hline
\end{tabular}




\begin{tabular}{|c|c|c|c|c|c|c|c|c|c|c|c|}
\hline \multirow[t]{2}{*}{ Country } & \multirow{2}{*}{$\begin{array}{l}\text { Percentage- } \\
\text { point } \\
\text { change }\end{array}$} & \multicolumn{2}{|c|}{ Injectable } & \multicolumn{2}{|c|}{ Survey year } & \multirow[t]{2}{*}{ Country } & \multirow{2}{*}{$\begin{array}{l}\text { Percentage- } \\
\text { point } \\
\text { change }\end{array}$} & \multicolumn{2}{|c|}{ Injectable } & \multicolumn{2}{|c|}{ Survey year } \\
\hline & & $\begin{array}{l}1995- \\
2000\end{array}$ & $\begin{array}{l}2001- \\
2012\end{array}$ & $\begin{array}{l}1995- \\
2000\end{array}$ & $\begin{array}{l}2001- \\
2012\end{array}$ & & & $\begin{array}{l}1995- \\
2000\end{array}$ & $\begin{array}{l}2001- \\
2012\end{array}$ & $\begin{array}{l}1995- \\
2000\end{array}$ & $\begin{array}{l}2001- \\
2012\end{array}$ \\
\hline Chad & 41.8 & 5.6 & 47.4 & 2000 & 2010 & Pakistan & 4.1 & 6.0 & 10.1 & 1997 & 2008 \\
\hline Rwanda & 35.7 & 15.8 & 51.6 & 2000 & 2010 & Laos & 4.1 & 24.0 & 28.0 & 2000 & 2005 \\
\hline Ethiopia & 34.2 & 38.8 & 73.0 & 2000 & 2011 & Costa Rica & 4.0 & 7.4 & 11.4 & 1999 & 2010 \\
\hline Mali & 32.0 & 3.2 & 35.2 & 1996 & 2006 & Philippines & 3.9 & 5.4 & 9.4 & 2000 & 2011 \\
\hline Sierra Leone & 27.5 & 22.0 & 49.5 & 2000 & 2010 & Brazil & 3.4 & 1.6 & 5.0 & 1996 & 2006 \\
\hline Eritrea & 27.3 & 16.0 & 43.3 & 1995 & 2002 & Dominican Rep. & 3.3 & 2.5 & 5.8 & 2000 & 2007 \\
\hline Uganda & 26.8 & 21.2 & 48.0 & 1995 & 2011 & Ecuador & 2.9 & 5.3 & 8.2 & 1999 & 2004 \\
\hline Haiti & 24.9 & 42.9 & 67.8 & 2000 & 2012 & Iraq & 2.8 & 3.8 & 6.5 & 2000 & 2011 \\
\hline Nicaragua & 24.1 & 8.7 & 32.7 & 1998 & 2007 & Jamaica & 2.4 & 16.6 & 19.0 & 1997 & 2009 \\
\hline Myanmar & 22.9 & 37.3 & 60.2 & 1997 & 2010 & Uzbekistan & 2.4 & 2.0 & 4.3 & 2000 & 2006 \\
\hline Honduras & 19.0 & 2.2 & 21.2 & 1996 & 2006 & Peru & 2.3 & 22.0 & 24.2 & 2000 & 2011 \\
\hline Kenya & 17.7 & 31.1 & 48.8 & 1998 & 2009 & Morocco & 2.2 & 1.3 & 3.5 & 1997 & 2004 \\
\hline Burkina Faso & 17.5 & 11.3 & 28.8 & 1999 & 2011 & Mexico & 2.1 & 5.4 & 7.5 & 1995 & 2006 \\
\hline Senegal & 17.3 & 25.0 & 42.3 & 1999 & 2011 & Angola & 1.9 & 21.8 & 23.7 & 1996 & 2001 \\
\hline Guatemala & 17.0 & 10.2 & 27.2 & 1999 & 2009 & Vietnam & 1.7 & 0.5 & 2.2 & 2000 & 2011 \\
\hline El Salvador & 16.3 & 14.9 & 31.2 & 1998 & 2008 & Egypt & 1.6 & 11.2 & 12.7 & 2000 & 2008 \\
\hline Guinea & 15.8 & 16.7 & 32.5 & 1999 & 2012 & Togo & 1.5 & 18.9 & 20.4 & 2000 & 2006 \\
\hline Benin & 15.4 & 4.6 & 20.0 & 1996 & 2012 & CAR & 1.4 & 2.7 & 4.1 & 2000 & 2010 \\
\hline Zambia & 12.9 & 12.4 & 25.4 & 1999 & 2007 & Cuba & 0.9 & 1.0 & 1.9 & 2000 & 2006 \\
\hline Bolivia & 12.5 & 6.5 & 19.0 & 2000 & 2008 & Turkey & 0.4 & 0.8 & 1.2 & 1998 & 2008 \\
\hline Burundi & 12.2 & 35.3 & 47.5 & 2000 & 2012 & Kyrgyz Rep. & 0.3 & 2.2 & 2.6 & 1997 & 2006 \\
\hline Niger & 11.7 & 13.6 & 25.3 & 2000 & 2012 & Jordan & 0.1 & 1.4 & 1.5 & 1997 & 2012 \\
\hline Nigeria & 11.6 & 16.7 & 28.2 & 1999 & 2012 & Belarus & 0.0 & 0.0 & 0.0 & 1995 & 2005 \\
\hline Somalia & 11.1 & 0.0 & 11.1 & 1999 & 2006 & Bosnia & 0.0 & 0.0 & 0.0 & 2000 & 2012 \\
\hline Madagascar & 9.2 & 37.2 & 46.4 & 2000 & 2009 & Georgia & 0.0 & 0.0 & 0.0 & 2000 & 2005 \\
\hline Ghana & 8.9 & 18.7 & 27.6 & 1999 & 2008 & Mozambique & 0.0 & 45.1 & 45.1 & 1997 & 2011 \\
\hline Indonesia & 8.6 & 43.3 & 51.9 & 2000 & 2012 & Serbia & 0.0 & 0.0 & 0.0 & 2000 & 2010 \\
\hline Sudan & 8.0 & 0.0 & 8.0 & 1999 & 2006 & Armenia & -0.2 & 0.2 & 0.0 & 2000 & 2010 \\
\hline Paraguay & 7.8 & 13.1 & 20.9 & 1998 & 2008 & Albania & -0.3 & 1.3 & 1.0 & 2000 & 2009 \\
\hline Cameroon & 7.7 & 5.6 & 13.3 & 2000 & 2011 & Gabon & -0.4 & 1.7 & 1.3 & 2000 & 2012 \\
\hline Mongolia & 7.7 & 9.3 & 17.0 & 2000 & 2008 & Kazakhstan & -0.4 & 1.0 & 0.6 & 1999 & 2011 \\
\hline Yemen & 7.4 & 9.4 & 16.8 & 1997 & 2006 & Tunisia & -0.6 & 3.0 & 2.3 & 2000 & 2006 \\
\hline Afghanistan & 6.7 & 28.3 & 35.0 & 2000 & 2011 & Malawi & -0.8 & 58.4 & 57.6 & 2000 & 2010 \\
\hline Colombia & 6.4 & 5.3 & 11.7 & 2000 & 2010 & Azerbaijan & -0.8 & 0.8 & 0.0 & 2000 & 2006 \\
\hline Sri Lanka & 6.4 & 15.7 & 22.2 & 2000 & 2007 & Zimbabwe & -1.2 & 15.5 & 14.3 & 1999 & 2011 \\
\hline South Africa & 6.1 & 41.4 & 47.4 & 1998 & 2003 & Namibia & -3.3 & 43.5 & 40.2 & 2000 & 2007 \\
\hline Guinea-Bissau & 7.7 & 7.9 & 17.0 & 2000 & 2010 & Lesotho & -5.1 & 46.6 & 41.5 & 2000 & 2009 \\
\hline Tanzania & 5.0 & 28.1 & 33.1 & 1999 & 2010 & Thailand & -5.8 & 23.5 & 17.7 & 1997 & 2009 \\
\hline Bangladesh & 4.8 & 13.6 & 18.5 & 2000 & 2011 & Botswana & -7.9 & 19.1 & 11.2 & 2000 & 2008 \\
\hline Tajikistan & 4.5 & 2.7 & 7.2 & 2000 & 2012 & Swaziland & -9.5 & 42.6 & 33.1 & 2000 & 2010 \\
\hline Côte d'Ivoire & 4.4 & 10.1 & 14.5 & 1999 & 2011 & Nepal & -9.9 & 28.4 & 18.5 & 2000 & 2011 \\
\hline Timor-Leste & 4.1 & 67.6 & 71.7 & 1997 & 2010 & Cambodia & -10.9 & 31.5 & 20.6 & 2000 & 2010 \\
\hline
\end{tabular}

